\title{
Structure and Reactivity of a Manganese(VI) Nitrido Complex bearing a Tetraamido Macrocyclic Ligand
}

Huatian Shi, ${ }^{a}$ Hung Kay Lee, ${ }^{\mathrm{b}}$ Yi Pan, ${ }^{\mathrm{a}}$ Kai-Chung Lau, ${ }^{\mathrm{a}}$ Shek-Man Yiu, ${ }^{\mathrm{a}}$ William W. Y. Lam, ${ }^{\mathrm{c}}$ Wai-Lun Man ${ }^{\mathrm{d}, *}$ and Tai-Chu Lau ${ }^{\mathrm{a}, *}$

aDepartment of Chemistry, City University of Hong Kong, Tat Chee Avenue, Kowloon Tong, Hong Kong, P. R. China

bDepartment of Chemistry, The Chinese University of Hong Kong, Shatin, New Territories, Hong Kong, P. R. China

${ }^{c}$ Faculty of Science and Technology, Technological and Higher Education Institute of Hong Kong, Tsing Yi Road, Tsing Yi Island, Hong Kong, P. R. China

${ }^{\mathrm{d}}$ Department of Chemistry, Hong Kong Baptist University, Waterloo Road, Kowloon Tong, Hong Kong, P. R. China

*To whom all correspondence should be addressed. Email: wlman118@hkbu.edu.hk (W.-L. M); bhtclau@ cityu.edu.hk (T.-C. L)

\section{Table of contents}

Experimental Section $\quad 2$

1. Materials 2

2. Instrumentation 2

3. Synthesis 3

4. X-ray crystallography 4

5. EPR spectroscopy 4

6. Kinetic studies 4

7. Product analysis 5

8. Computational studies 5

Supplemental References

Supplemental Figures $\quad 9$

Supplemental Tables 23 


\section{Materials}

The tetraamido macrocyclic ligand (H4TAML), Li[Mn $\left.{ }^{\mathrm{III}}(\mathrm{TAML})\right],\left[\mathrm{Cp}_{2} \mathrm{Fe}\right]\left[\mathrm{BAr}_{4}^{\mathrm{F}}\right]$ and 2phenylaziridine were prepared according to the reported procedures. ${ }^{1-4} 2-(p$ methylphenyl)aziridine and 2-( $p$-chlorophenyl)aziridine were prepared by $\mathrm{N}$-atom transfer of $\mathrm{Mn}^{\mathrm{V}}(\mathrm{N})\left(\right.$ salen) to 4-methylstyrene and 4-chlorostyrene, respectively. ${ }^{5}$ All styrene and its derivatives were passed through a short basic alumina column before use. Other chemicals and solvents were used as received unless otherwise stated. 9,10-Dihydro-10-methylacridine $\left(\mathrm{AcrH}_{2}\right)$ was prepared from 10-methylacridinium iodide $\left(\mathrm{AcrH}^{+} \mathrm{I}^{-}\right)$by reduction with $\mathrm{NaBH}_{4}$ in methanol and purified by recrystallization from ethanol and $\mathrm{AcrD}_{2}$ was prepared reduction of 10-methylacridone by $\mathrm{LiAlD}_{4}$ in ether. ${ }^{6}$

\section{Instrumentation}

UV-vis spectroscopy was performed with an Agilent $8543 \mathrm{UV}$-vis spectrophotometer equipped with a circulating water bath. Infrared spectra $(\mathrm{KBr})$ were recorded on a Nicolet iS50 FTIR spectrometer. ESI/MS was conducted on an AB SCIEX API3200 mass spectrometer. Cyclic voltammetry was performed on a CHI-660c electrochemical workstation with a three-electrode system consisting of a glassy-carbon working electrode, a SCE reference electrode and a platinum wire counter electrode, with $0.1 \mathrm{M}\left[{ }^{\mathrm{n}} \mathrm{Bu}_{4} \mathrm{~N}\right]\left(\mathrm{PF}_{6}\right)$ as supporting electrolyte. ${ }^{1} \mathrm{H}$ NMR spectra were recorded on a Bruker $300 \mathrm{MHz}$ or $400 \mathrm{MHz}$ spectrometer. ${ }^{15} \mathrm{~N}$ NMR was recorded on a $600 \mathrm{MHz}$ Bruker spectrometer, and the chemical shift was referenced to nitromethane and reported against $\mathrm{NH}_{3}$. GC-FID was performed on a HP6890 series gas chromatography equipped with a HP-5MS capillary column, and GC-TCD was conducted on an Agilent 6890 series gas chromatography equipped with a molecular sieves column. GC-MS was done with an Agilent 6890/5975N gas chromatograph-mass selective detector system equipped with a HP-5MS capillary column. Electron paramagnetic resonance (EPR) spectra were recorded on a Bruker EMX spectrometer at $7 \mathrm{~K}$ equipped with a variable temperature helium flow cryostat system (Oxford Instrument). Kinetic studies were performed on an Agilent $8543 \mathrm{UV}-\mathrm{Vis}$ spectrophotometer or an Applied Photophysic SX20 Stopped Flow spectrometer. 


\section{Synthesis}

(PPh4)2[MnV(N)TAML] (PPh4)2-1. $2 \mathrm{~mL} \mathrm{NH}{ }_{4} \mathrm{OH}$ (25\% aqueous solution) was added dropwise to a solution containing $\mathrm{Li}\left[\mathrm{Mn}^{\mathrm{III}}(\mathrm{TAML})\right] \cdot 2 \mathrm{CH}_{3} \mathrm{OH}(200 \mathrm{mg}, 0.46 \mathrm{mmol})$ in $100 \mathrm{ml}$ $\mathrm{MeOH}$ and the mixture was stirred for $5 \mathrm{~min}$ at room temperature. Then $3.75 \mathrm{ml}$ of Clorox Bleach containing $6.25 \% \mathrm{NaClO}(2.78 \mathrm{mmol})$ was added and the solution was further stirred for $1 \mathrm{~h}$ at room temperature. The solvent was removed and the resulting solid was re-dissolved in a minimum amount of water. Addition of a solution containing $1 \mathrm{~g} \mathrm{PPh} 4 \mathrm{Cl}$ in $10 \mathrm{ml} \mathrm{H}_{2} \mathrm{O}$ produced a reddish orange precipitate, which was filtered and recrystallized from $\mathrm{CH}_{3} \mathrm{CN} /$ diethyl ether. Yield: 75\%. Single crystals suitable for X-ray analysis were obtained by slow diffusion of $\mathrm{Et}_{2} \mathrm{O}$ into a $\mathrm{CH}_{3} \mathrm{CN}$ solution of $\mathbf{1}$ at room temperature. $\mathbf{1 -}^{\mathbf{1 5}} \mathbf{N}$ was prepared with a similar procedure except using ${ }^{15} \mathrm{NH}_{4} \mathrm{Cl}$ and 1 equiv. $\mathrm{NaOH}$ in $\mathrm{CH}_{3} \mathrm{OH}$ as ${ }^{15} \mathrm{~N}$ atom source. (400 MHz, $d_{6}$-DMSO): 8.16(m, 2H, ArH-TAML), 7.96(t, 8H, ArH-Ph $\left.{ }_{4} \mathrm{P}\right), 7.82(\mathrm{~m}, 16 \mathrm{H}$, $\left.\mathrm{ArH}-\mathrm{Ph}_{4} \mathrm{P}\right), 7.75\left(\mathrm{~m}, 16 \mathrm{H}, \mathrm{ArH}-\mathrm{Ph}{ }_{4} \mathrm{P}\right), 6.56(\mathrm{~m}, 2 \mathrm{H}, \mathrm{ArH}-\mathrm{TAML}), 1.54\left(\mathrm{~s}, 3 \mathrm{H},-\mathrm{CH}_{3}\right), 1.48(\mathrm{~s}$, $\left.6 \mathrm{H},-\mathrm{CH}_{3}\right), 1.37\left(\mathrm{~s}, 6 \mathrm{H},-\mathrm{CH}_{3}\right), 1.13\left(\mathrm{~s}, 3 \mathrm{H},-\mathrm{CH}_{3}\right) .{ }^{15} \mathrm{~N} \mathrm{NMR}\left(600 \mathrm{MHz}, \mathrm{CDCl}_{3}\right): 963 \mathrm{ppm} .{ }^{15} \mathrm{~N}$ NMR (600 MHz, $\mathrm{CDCl}_{3}$ ): 968.83 ppm. ESI/MS (-ve mode): $m / z$ 219.7, 439.7and 778.7. IR (KBr disc): $1051 \mathrm{~cm}^{-1}(\mathrm{Mn} \equiv \mathrm{N}), 1027 \mathrm{~cm}^{-1}\left(\mathrm{Mn} \equiv{ }^{15} \mathrm{~N}\right) . \mathrm{UV}$-vis $\left(\mathrm{CH}_{3} \mathrm{CN}\right): 196 \mathrm{~nm}$ (23425), 228 $\mathrm{nm}$ (sh, 8340), $269 \mathrm{~nm}$ (2185), $276 \mathrm{~nm}$ (2250). Anal. calcd. (found) for $\mathrm{C}_{67} \mathrm{H}_{62} \mathrm{MnN}_{5} \mathrm{O}_{4} \mathrm{P}_{2}: \mathrm{C}$, 71.97 (71.86); H, 5.59 (5.89); N, 6.26 (6.16).

$(\mathbf{P P h} 4)\left[\mathbf{M n}^{\mathrm{VI}}(\mathbf{N}) \mathrm{TAML} \cdot \mathbf{E t} \mathbf{t}_{2} \mathrm{O}\left(\mathbf{P P h}_{4}\right)-2\right.$. To a solution of $(\mathbf{P P h})_{2}-\mathbf{1}(60 \mathrm{mg}, 0.054 \mathrm{mmol})$ in $\mathrm{CH}_{2} \mathrm{Cl}_{2}(6 \mathrm{ml})$ was added $\left[\mathrm{Cp}_{2} \mathrm{Fe}\right]\left[\mathrm{BAr}_{4}{ }_{4}\right](58 \mathrm{mg}, 0.054 \mathrm{mmol})$ at $0{ }^{\circ} \mathrm{C}$ and the mixture was sonicated to give a homogeneous dark brown solution. $\mathrm{Et}_{2} \mathrm{O}(120 \mathrm{ml})$ at $0{ }^{\circ} \mathrm{C}$ was then added and the mixture was allowed to stand at $-40{ }^{\circ} \mathrm{C}$ to produce brown needle shape crystals after 2 d. Yield $90 \%$. The ${ }^{15} \mathrm{~N}$ labelled $\left(\mathrm{PPh}_{4}\right)\left[\mathrm{Mn}^{\mathrm{VI}}\left({ }^{15} \mathrm{~N}\right)(\mathrm{TAML})\right]$ was prepared in a similar procedure except using ${ }^{15} \mathrm{~N}$-labelled (PPh4)2-1. IR: $967 \mathrm{~cm}^{-1}(\mathrm{Mn} \equiv \mathrm{N}), 944 \mathrm{~cm}^{-1}\left(\mathrm{Mn} \equiv{ }^{15} \mathrm{~N}\right)$. ESI/MS (-ve mode): $m / z$ 439. UV-vis $\left(\mathrm{CH}_{3} \mathrm{CN}\right): 435 \mathrm{~nm}$ (sh, 11590), $660 \mathrm{~nm}$ (270), $955 \mathrm{~nm}$ (80). Anal. calcd. (found) for $\mathrm{C}_{47} \mathrm{H}_{52} \mathrm{MnN}_{5} \mathrm{O}_{5} \mathrm{P}: \mathrm{C}, 66.19$ (66.19); H, 6.15 (6.11); N, 8.21 (7.95).

(PPh4) $\left[\mathbf{M n}^{\mathbf{V}} \mathbf{( N ) T A M L - H ^ { + } ]}\right.$ (PPh4)-3. $0.5 \mathrm{ml}$ of a solution of $\mathrm{CF}_{3} \mathrm{COOH}(0.1 \mathrm{mmol})$ in $\mathrm{CH}_{3} \mathrm{CN}$ was added to $\left(\mathbf{P P h}_{4}\right)_{2}-\mathbf{1}(0.112 \mathrm{mg}, 0.1 \mathrm{mmol})$ in $\mathrm{CH}_{3} \mathrm{CN}$ and a yellow orange crystalline solid was formed immediately. The solid was collected by filtration and washed by $\mathrm{CH}_{3} \mathrm{CN}(5 \mathrm{ml} \times$ 3). (Yield: 95\%). Single crystals suitable for X-ray crystallography were obtained from 
$\mathrm{CH}_{3} \mathrm{OH} / \mathrm{Et}_{2} \mathrm{O}$. ESI/MS (-ve mode): $\mathrm{m} / z$ 440.3. IR ( $\mathrm{KBr}$ disc): 1060 and $1055 \mathrm{~cm}^{-1}(\mathrm{Mn} \equiv \mathrm{N})$, $1032 \mathrm{~cm}^{-1}\left(\mathrm{Mn} \equiv{ }^{15} \mathrm{~N}\right){ }^{1} \mathrm{H}$ NMR(400 MHz, CD $\left.{ }_{3} \mathrm{OD}\right): 8.21$ (dd, 2H, ArH(TAML)), 7.95 (m, 4H, $\left.\operatorname{ArH}\left(\mathrm{Ph}_{4} \mathrm{P}^{+}\right)\right)$, 7.83-7.70 (m, 16H, $\left.\mathrm{ArH}\left(\mathrm{Ph}_{4} \mathrm{P}^{+}\right)\right), 6.85$ (dd, 2H, $\left.\operatorname{ArH}(\mathrm{TAML})\right), 1.79$ (s, 3H, $-\mathrm{CH}_{3}$ (TAML)), 1.79 (s, 3H, - $\mathrm{CH}_{3}$ (TAML)), 1.66 (s, 6H, - $\mathrm{CH}_{3}$ (TAML)), 1.63 (s, 6H, - $\mathrm{CH}_{3}$ (TAML)), 1.52 (s, 3H, - $\mathrm{CH}_{3}$ (TAML)). Anal. calcd. (found) for $\mathrm{C}_{43} \mathrm{H}_{43} \mathrm{MnN}_{5} \mathrm{O}_{4} \mathrm{P}: \mathrm{C}, 66.23$ (66.20); H, 5.56 (5.75); N, $8.98(8.86)$.

4. X-ray crystallography. Crystals were sealed in a loop and mounted on a goniometer head. Data were collected on a Bruker D8 Venture Photon II diffractometer using Mo-K $\alpha$ radiation $(\lambda=0.71073 \AA)$ for 1 at $173 \mathrm{~K}$ and $\mathrm{Cu}-\mathrm{K} \alpha$ radiation $(\lambda=1.54178 \AA)$ for 2 and 3 at 240 and $213 \mathrm{~K}$, respectively. The collected frames were processed with the Apex3 software. The structures were solved with the program SHELXS-2014 and were refined on $F^{2}$ with SHELXL-2014 in Olex2 program package..$^{7-9}$

5. EPR Spectroscopy. A solution of 2 in $\mathrm{CH}_{3} \mathrm{CN}$ was freshly prepared at room temperature by mixing $2 \mathrm{mM} 1$ with $2 \mathrm{mM}\left[\left(p-\mathrm{Br}_{-} \mathrm{C}_{6} \mathrm{H}_{4}\right)_{3} \mathrm{~N}^{+}\right]\left[\mathrm{SbCl}_{6}\right]$ and then transferred into an EPR tube. The sample was frozen in liquid nitrogen immediately and kept in liquid nitrogen until EPR measurement. EPR measurement parameter: microwave power $=2.0 \mathrm{~mW}$, frequency $=9.399$ $\mathrm{GHz}$, receive gain $=5.64 \times 10^{4}$, modulation amplitude $=1 \mathrm{G}$, and modulation frequency $=100$ $\mathrm{kHz}$. Spectral simulation was performed by using the Easyspin toolbox in Matlab. ${ }^{10}$

6. Kinetic Studies. Kinetic studies were carried out on an Agilent 8543 UV-vis spectrophotometer or an Applied Photophysic SX20 Stopped Flow spectrometer.

(A) Reaction of 2 with $\mathrm{PPh}_{3}$. The kinetics of 2 and $\mathrm{PPh}_{3}$ were performed with an Applied Photophysic SX20 Stopped Flow spectrometer by monitoring the absorbance at $553 \mathrm{~nm}$.

(B) Reaction of 2 with styrenes. The kinetics of 2 with at least 10 -fold excess $p$-substitutedstyrenes were performed using a two-compartment cuvette. Spectral changes were recorded after mixing 2 and substrates. The pseudo-first order rate constants, $k_{o b s}$, were obtained by nonlinear least-squares fits of $A_{t}$ at $436 \mathrm{~nm}$ versus time $t$ according to the equation $A_{t}=A_{\infty}+$ $\left(A_{0}-A_{\infty}\right) \exp \left(k_{\mathrm{obs}} t\right)$, where $A_{0}$ and $A_{\infty}$ are the initial and final absorbance, respectively. ${ }^{11}$ Linear 
plot of the pseudo-first order rate constants, $k_{o b s}$, versus substrates concentration obtained the second order rate constants, $k_{2}$.

(C) $N \cdots N$ coupling reaction of 2 . The reaction rates of bimolecular $\mathrm{N}-\mathrm{N}$ coupling reaction of 2 were obtained by linear fitting to the equation $1 /[\mathrm{A}]=1 /\left[\mathrm{A}_{0}\right]+k x .^{11}$

(D) Reaction of $\mathbf{2}$ with NADH analogues. The kinetics of $\mathbf{2}$ and NADH analogues were conducted on an Agilent $8543 \mathrm{UV}$-vis spectrophotometer by monitoring the absorbance at 450 $\mathrm{nm}$ for BNAH in a $1 \mathrm{~cm}$ two-compartment cuvette and $660 \mathrm{~nm}$ for $\mathrm{AcrH}_{2}$ and $\mathrm{AcrD}_{2}$ in a $5 \mathrm{~cm}$ cuvette.

\section{Product Analysis.}

(A) Aziridines. The amount of various aziridines was determined for the reaction of 2 with $p$ substituted aziridines by the following procedure. A mixture containing $2.5 \mu \mathrm{mol} 1$ and $1 \mathrm{~mL}$ styrene was added to $2.5 \mu \mathrm{mol}\left[\mathrm{Cp}_{2} \mathrm{Fe}\right]\left[\mathrm{BAr}_{4}\right]$ in $10 \mathrm{~mL} \mathrm{CH}_{2} \mathrm{Cl}_{2}$ and the solution was stirred for $15 \mathrm{~h}$ in air. 1,2,4-trichlorobenzene was then added as an internal standard, and the mixture was analyzed by GC-FID.

(B) $B N A^{+}$. The amount of $\mathrm{BNA}^{+}$after the reaction of 2 and $\mathrm{BNAH}$ was determined by the following procedure. A known amount of $2(2.0 \mu \mathrm{mol})$ was allowed to react with of $19.6 \mu \mathrm{mol}$ BNAH under argon in $0.5 \mathrm{~mL} \mathrm{CD}_{3} \mathrm{CN}$ at room temperature. After10 min., $0.54 \mu \mathrm{mol} \mathrm{DMF}$ was added as internal standard and the solution was analyzed by ${ }^{1} \mathrm{H}$ NMR. The formation of $\mathrm{BNA}^{+}$was monitored at $9.27,8.91$ and $8.74 \mathrm{ppm}$ with reference to the DMF standard at 2.96 and $2.84 \mathrm{ppm}$. The amount of $\mathrm{BNA}^{+}$produced was found to be $0.94 \pm 0.02 \mu \mathrm{mol}$ (average of three independent experiments).

8. Computational studies. Calculations on $\mathbf{1}, \mathbf{2}$ and $\mathbf{3}$ utilized density functional theory (DFT) as implemented in Orca 4.2.1 program package. $^{12-13}$ Geometry optimization was performed with BP86 functional without imposing any symmetry constraints. ${ }^{14-15}$ The resolution of identity (RI) approximation, atom-pairwise dispersion corrections in the Becke-Johnson damping scheme (D3BJ) and scalar relativistic corrections with zeroth-order regular approximation (ZORA) methods were adapted. ${ }^{16-17}$ A relativistically recontracted version of the all-electron def2-TZVP Ahlrichs basis set (ZORA-def2-TZVP) and SARC/J auxiliary basis 
were used for geometry optimizations on all atoms. ${ }^{18-23}$ Tight optimization and tight selfconsistent field convergence with a fine Orca grid (Grid5, FinalGrid6) were employed in all geometry optimization calculations. The initial geometries of manganese complexes were obtained from the X-ray crystal structures of Mn nitrido complexes. Frequency calculation was performed on the equilibrium structures at the same level of theory to make sure local minimum of the geometry (without any imaginary frequency). Complete active space self-consistent field (CASSCF) theory calculation on the equilibrium structure of $\mathbf{2}$ was performed with the MOLPRO 2020.2 program using def2-TZVP basis set. ${ }^{23-25}$

\section{References}

1. Hong, S.; Sutherlin, K. D.; Park, J.; Kwon, E.; Siegler, M. A.; Solomon, E. I.; Nam, W., Crystallographic and spectroscopic characterization and reactivities of a mononuclear nonhaem iron(III)-superoxo complex. Nat. Commun. 2014, 5, 1-7.

2. Horwitz, C. P.; Ghosh, A., Synthesis of macrocyclic tetraamido compounds and new metal insertion process. US20040167329A1, 2004.

3. O' Connor, A. R.; Nataro, C.; Golen, J. A.; Rheingold, A. L., Synthesis and reactivity of $\left[\mathrm{N}\left(\mathrm{C}_{6} \mathrm{H}_{4} \mathrm{Br}\right)_{3}\right]\left[\mathrm{B}\left(\mathrm{C}_{6} \mathrm{~F}_{5}\right)_{4}\right]$ : the X-ray crystal structure of $\left[\mathrm{Fe}\left(\mathrm{C}_{5} \mathrm{H}_{5}\right)_{2}\right]\left[\mathrm{B}\left(\mathrm{C}_{6} \mathrm{~F}_{5}\right) 4\right] . J$. Organomet. Chem. 2004, 689 (14), 2411-2414.

4. Buckley, B. R.; Patel, A. P.; Wijayantha, K. G. U., Observations on the Modified Wenker Synthesis of Aziridines and the Development of a Biphasic System. J. Org. Chem. 2013, 78 (3), 1289-1292.

5. Ho, C. M.; Lau, T. C.; Kwong, H. L.; Wong, W. T., Activation of manganese nitrido complexes by Bronsted and Lewis acids. Crystal structure and asymmetric alkene aziridination of a chiral salen manganese nitrido complex. J. Chem. Soc. Dalton 1999, (15), 2411-2413.

6. (a) Roberts, R. M. G.; Ostović, D.; Kreevoy, M. M., Hydride transfer between NAD ${ }^{+}$ analogues. Faraday Discuss. Chem. Soc., 1982, 74, 257-265. (b)Fukuzumi, S.; Tokuda, Y.; Kitano, T.; Okamoto, T.; Otera, J., Electron-Transfer Oxidation of 9-Substituted 10Methyl-9,10-Dihydroacridines - Cleavage of the C-H vs C-C Bond of the Radical Cations. J. Am. Chem. Soc. 1993, 115 (20), 8960-8968. 
7. Dolomanov, O. V.; Bourhis, L. J.; Gildea, R. J.; Howard, J. A. K.; Puschmann, H. OLEX2: a complete structure solution, refinement and analysis program., J. Appl. Cryst. 2009, 42, 339-341.

8. Sheldrick, G. M. Crystal structure refinement with SHELXL. Acta Cryst. C 2015, 64, 112122.

9. Krause, L.; Herbst-Irmer, R.; Sheldrick, G. M.; Stalke, D. Comparison of silver and molybdenum microfocus X-ray sources for single-crystal structure determination. J. Appl. Cryst.2015 48, 3-10.

10. Stoll, S.; Schweiger, A., EasySpin, a comprehensive software package for spectral simulation and analysis in EPR. J. Magn. Reson. 2006, 178 (1), 42-55.

11. Espenson, J. H., Chemical kinetics and reaction mechanisms. McGraw-Hill New York: 1995; Vol. 102.

12. Neese, F., The ORCA program system. Wiley Interdiscip. Rev.: Comput. Mol. Sci. 2012, 2 , 73-78.

13. Neese, F., Software update: The ORCA program system, Version 4.0. Wiley Interdiscip. Rev.: Comput. Mol. Sci. 2018, 8, No. e1327.

14. Becke, A. D., Density-Functional Exchange-Energy Approximation with Correct Asymptotic-Behavior. Phys. Rev. A 1988, 38 (6), 3098-3100.

15. Perdew, J. P., Density-Functional Approximation for the Correlation-Energy of the Inhomogeneous Electron-Gas. Phys. Rev. B 1986, 33 (12), 8822-8824.

16. Grimme, S.; Antony, J.; Ehrlich, S.; Krieg, H., A consistent and accurate ab initio parametrization of density functional dispersion correction (DFT-D) for the 94 elements H-Pu. J. Chem. Phys. 2010, 132 (15).

17. Grimme, S.; Ehrlich, S.; Goerigk, L., Effect of the Damping Function in Dispersion Corrected Density Functional Theory. J. Comput. Chem. 2011, 32 (7), 1456-1465.

18. Pantazis, D. A.; Chen, X. Y.; Landis, C. R.; Neese, F., All-electron scalar relativistic basis sets for third-row transition metal atoms. J. Chem. Theory Comput. 2008, 4 (6), 908-919.

19. Pantazis, D. A.; Neese, F., All-Electron Scalar Relativistic Basis Sets for the Lanthanides. J. Chem. Theory Comput. 2009, 5 (9), 2229-2238. 
20. Pantazis, D. A.; Neese, F., All-Electron Scalar Relativistic Basis Sets for the Actinides. J. Chem. Theory Comput. 2011, 7 (3), 677-684

21. Pantazis, D. A.; Neese, F., All-electron scalar relativistic basis sets for the $6 p$ elements. Theor. Chem. Acc. 2012, 131 (11).

22. Weigend, F., Accurate Coulomb-fitting basis sets for H to Rn. PCCP 2006, 8 (9), 1057 1065 .

23. Weigend, F.; Ahlrichs, R., Balanced basis sets of split valence, triple zeta valence and quadruple zeta valence quality for $\mathrm{H}$ to $\mathrm{Rn}$ : Design and assessment of accuracy. PCCP 2005, 7 (18), 3297-3305.

24. (a) Werner, H. J.; Knowles, P. J. A second order multiconfiguration SCF procedure with optimum convergence. J. Chem. Phys. 1985, 82, 5053-5063. (b) Knowles, P. J.; Werner, H. J. An efficient second-order MC SCF method for long configuration expansions. Chem. Phys. Lett. 1985, 115, 259-267.

25. Werner, H. -J.; Knowles, P. J.; Knizia, G.; Manby, F. R.; Schütz, M.; Celani, P.; Györffy, W.; Kats, D.; Korona, T.; Lindh, R.; Mitrushenkov, A.; Rauhut, G.; Shamasundar, K. R.; Adler, T. B.; Amos, R. D.; Bernhardsson, A.; Berning, A.; Cooper, D. L.; Deegan, M. J. O.; Dobbyn, A. J.; Eckert, F.; Goll, E.; Hampel, C.; Hesselmann, A.; Hetzer, G.; Hrenar, T.; Jansen, G.; Köppl, C.; Liu, Y.; Lloyd, A. W.; Mata, R. A.; May, A. J.; McNicholas, S. J.; Meyer, W.; Mura, M. E.; Nicklass, A.; Palmieri, P.; Peng, D.; Pflüger, K.; Pitzer, R.; Reiher, M.; Shiozaki, T.; Stoll, H.; Stone, A. J.; Tarroni, R.; Thorsteinsson, T.; Wang, M.; Welborn, M. MOLPRO, version 2020.2, a package of ab initio programs. See http://www.molpro.net. 


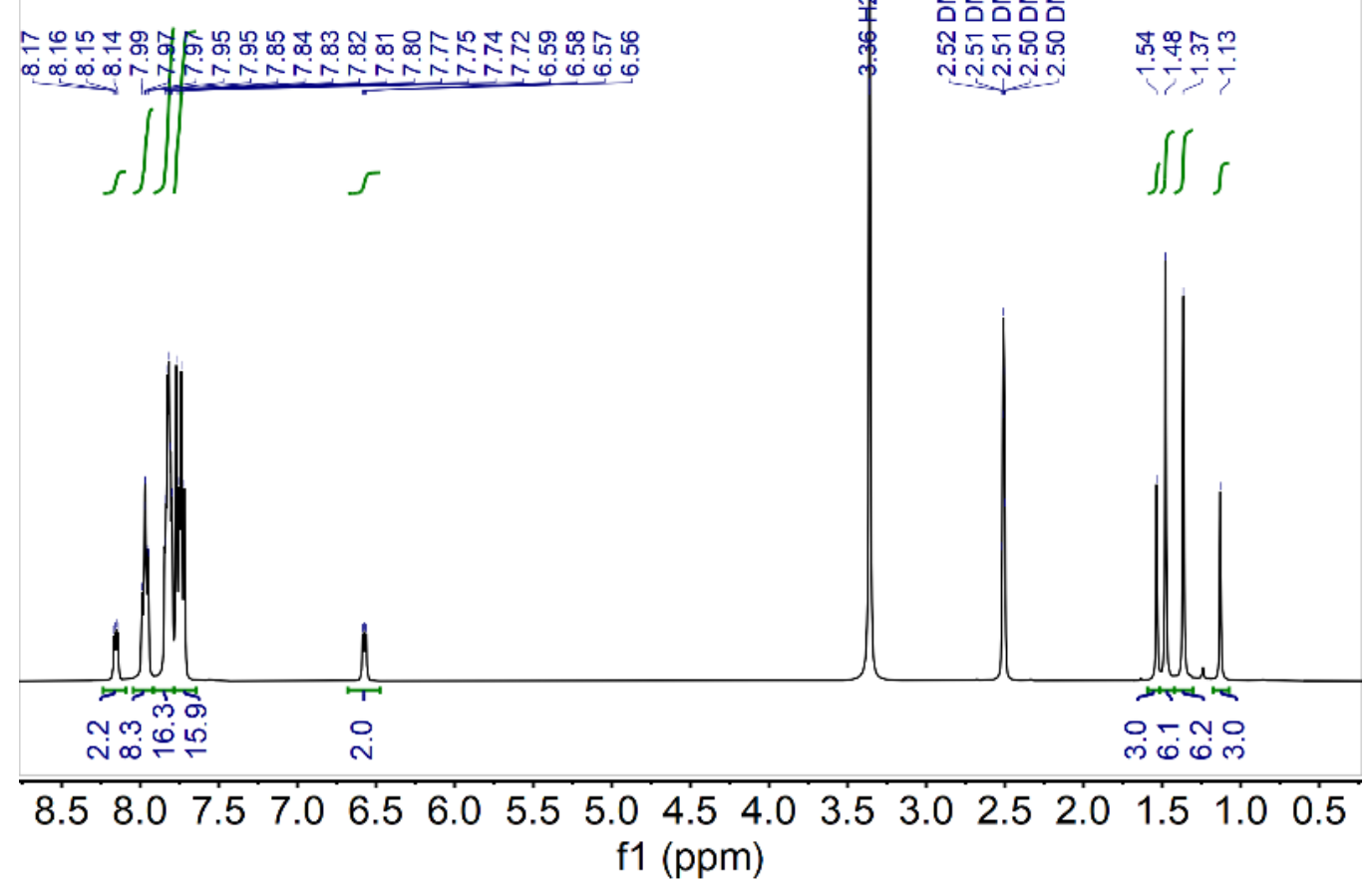

Figure S1. ${ }^{1} \mathrm{H}$ NMR of $\left(\mathbf{P P h}_{4}\right)_{2}-1$ in $d_{6}$-DMSO.

@
ஸें

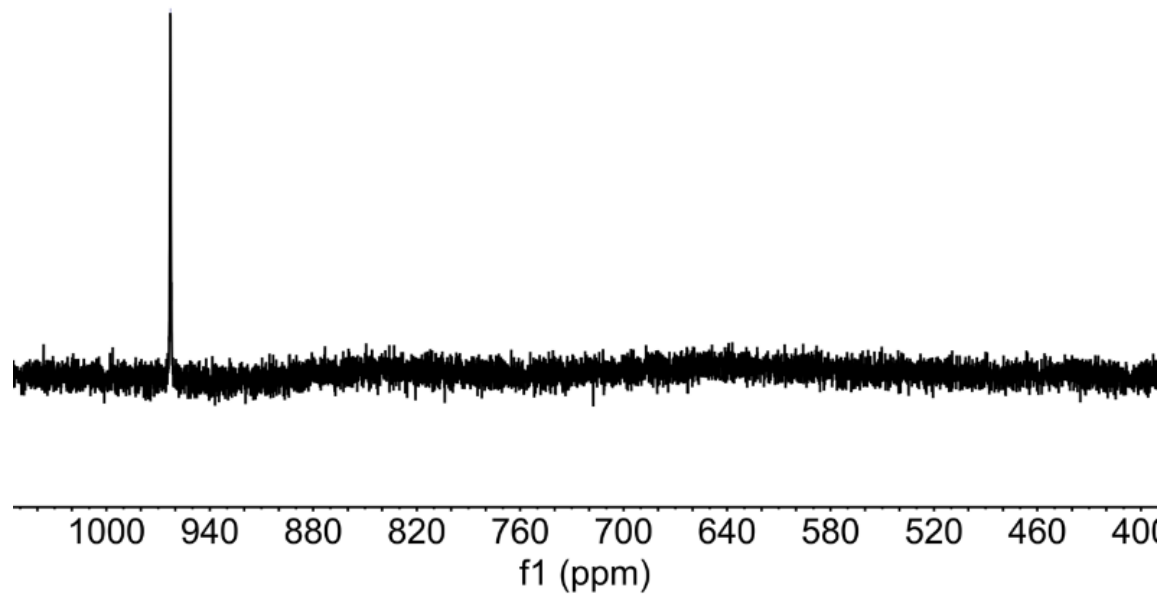

Figure S2. ${ }^{15} \mathrm{~N}$ NMR of $\mathbf{1 -}^{\mathbf{1 5}} \mathbf{N}$ in $\mathrm{CDCl}_{3}$. 


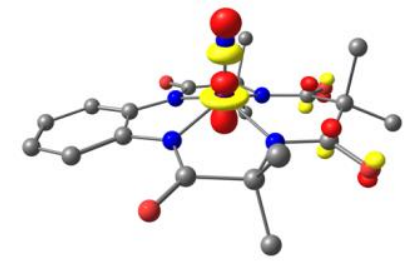

MO-121 (4.880 eV)

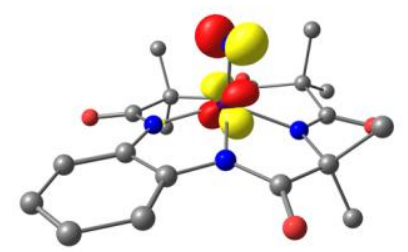

MO-119 (4.620 eV)

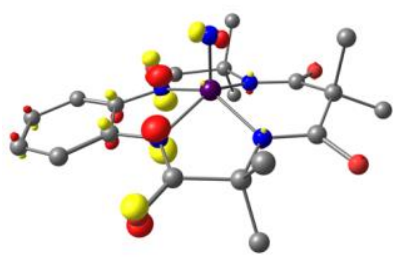

MO-115 (1.117 eV)
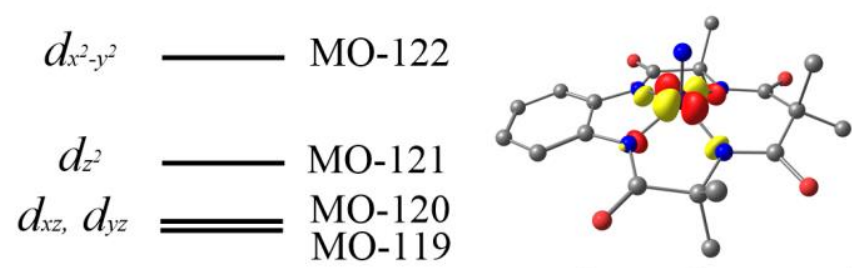

MO-122 (5.269 eV)

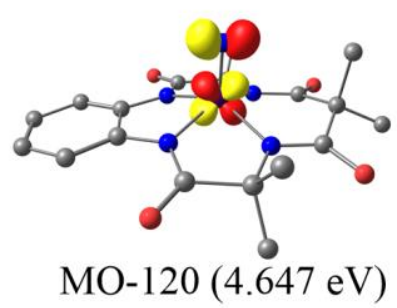

$d_{x y}$

TAML $\pi \stackrel{4}{\|}$ MO-115

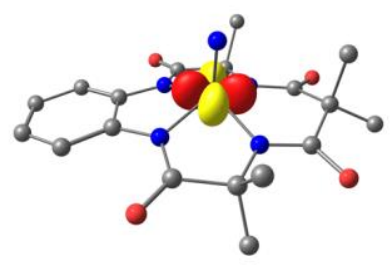

MO-116 (2.254 eV)

Figure S3. Molecular orbital diagram of $\left[\mathrm{Mn}^{\mathrm{V}}(\mathrm{N})(\mathrm{TAML})\right]^{2-}$.

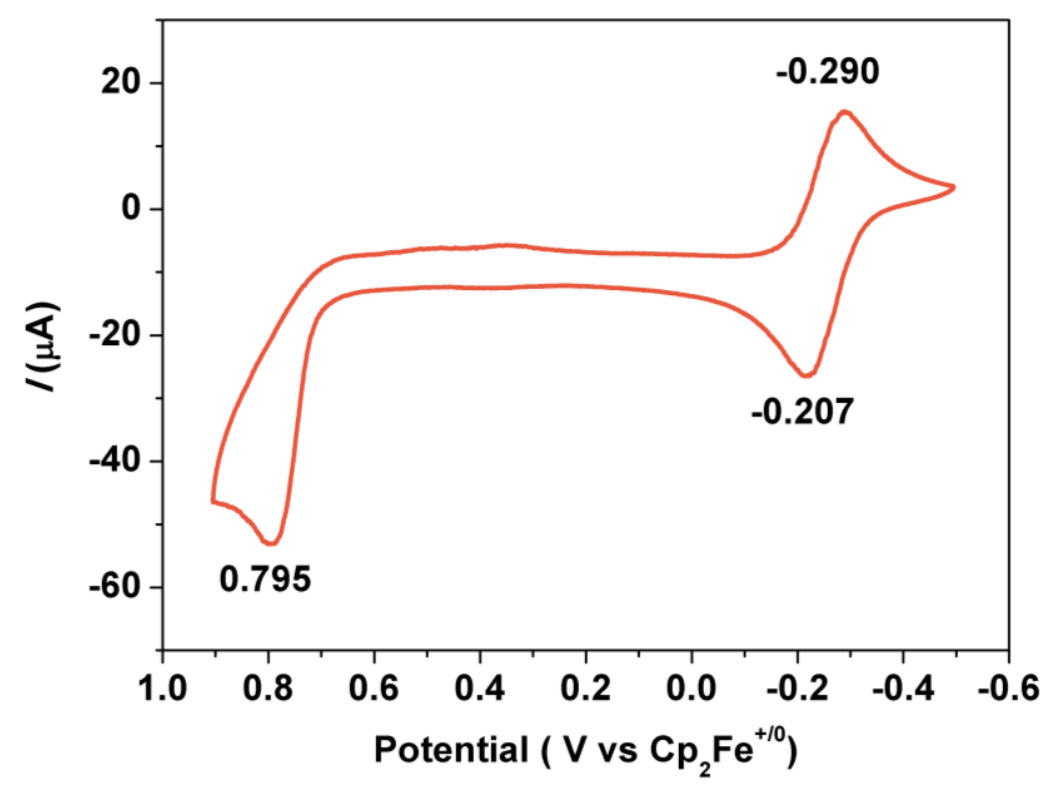

Figure S4. CV of 1 in $\mathrm{CH}_{3} \mathrm{CN}$. 


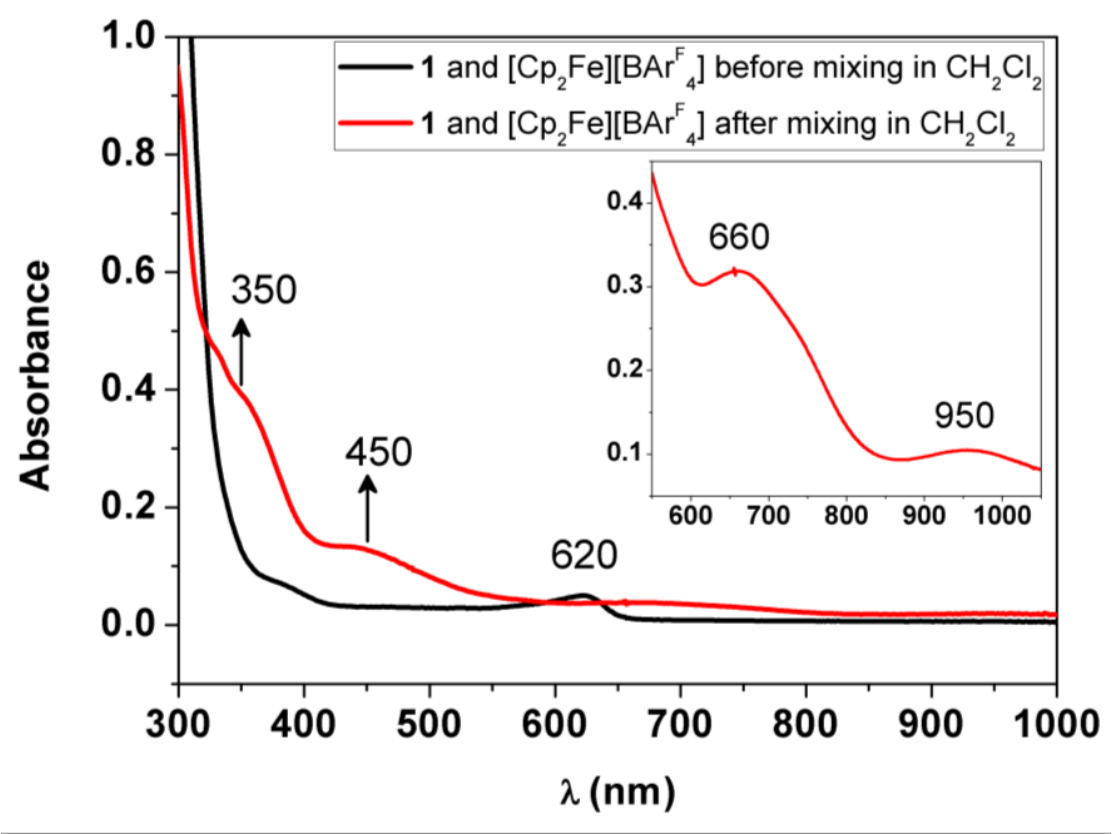

Figure S5. UV-vis spectra for the solution containing $0.2 \mathrm{mM} 1$ and $0.2 \mathrm{mM}\left[\mathrm{FeCp}_{2}\right]\left[\mathrm{BAr}_{4}{ }^{\mathrm{F}}\right]$ in $\mathrm{CH}_{2} \mathrm{Cl}_{2}$ in a two-compartment cuvette before mixing (black line) and after mixing (red line). Inset shows the expanded spectrum after mixture $1 \mathrm{mM} 1$ and $1 \mathrm{mM}[\mathrm{FeCp} 2]\left[\mathrm{BAr}_{4}^{\mathrm{F}}\right]$ in $\mathrm{CH}_{2} \mathrm{Cl}_{2}$.

(a)

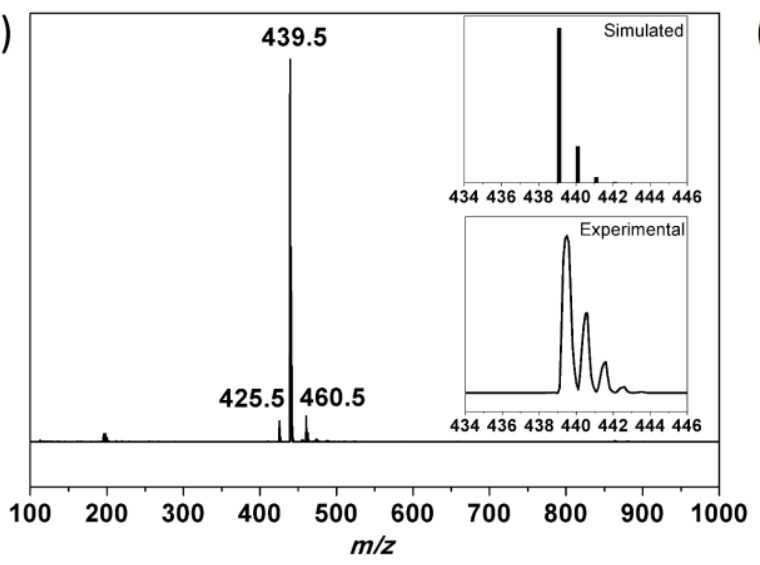

(b)

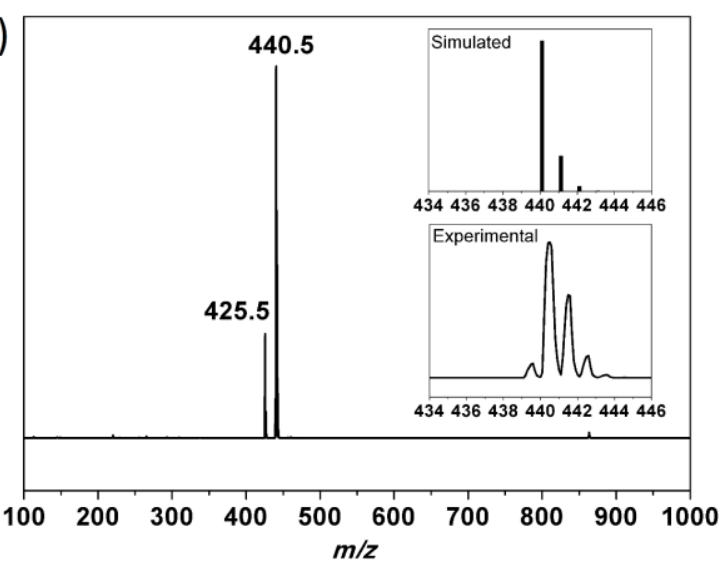

Figure S6. ESI/MS (negative mode) of (a) 2 and (b) $2-{ }^{15} \mathbf{N}$. 


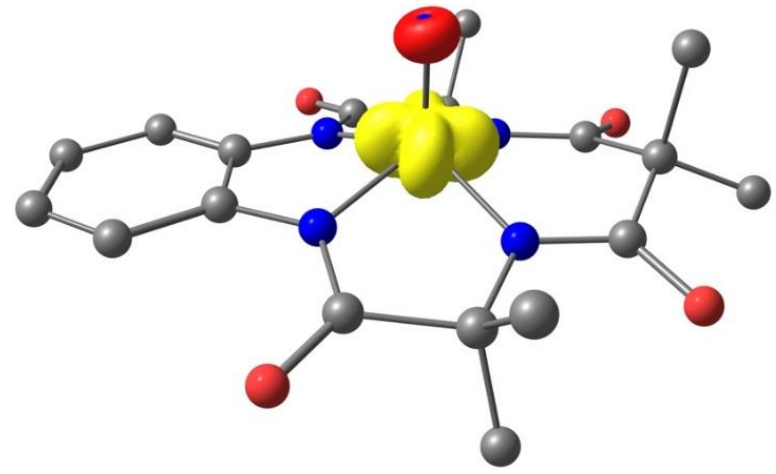

Figure S7. Spin density plot $(\alpha-\beta)$ of equilibrium structure of 2 .

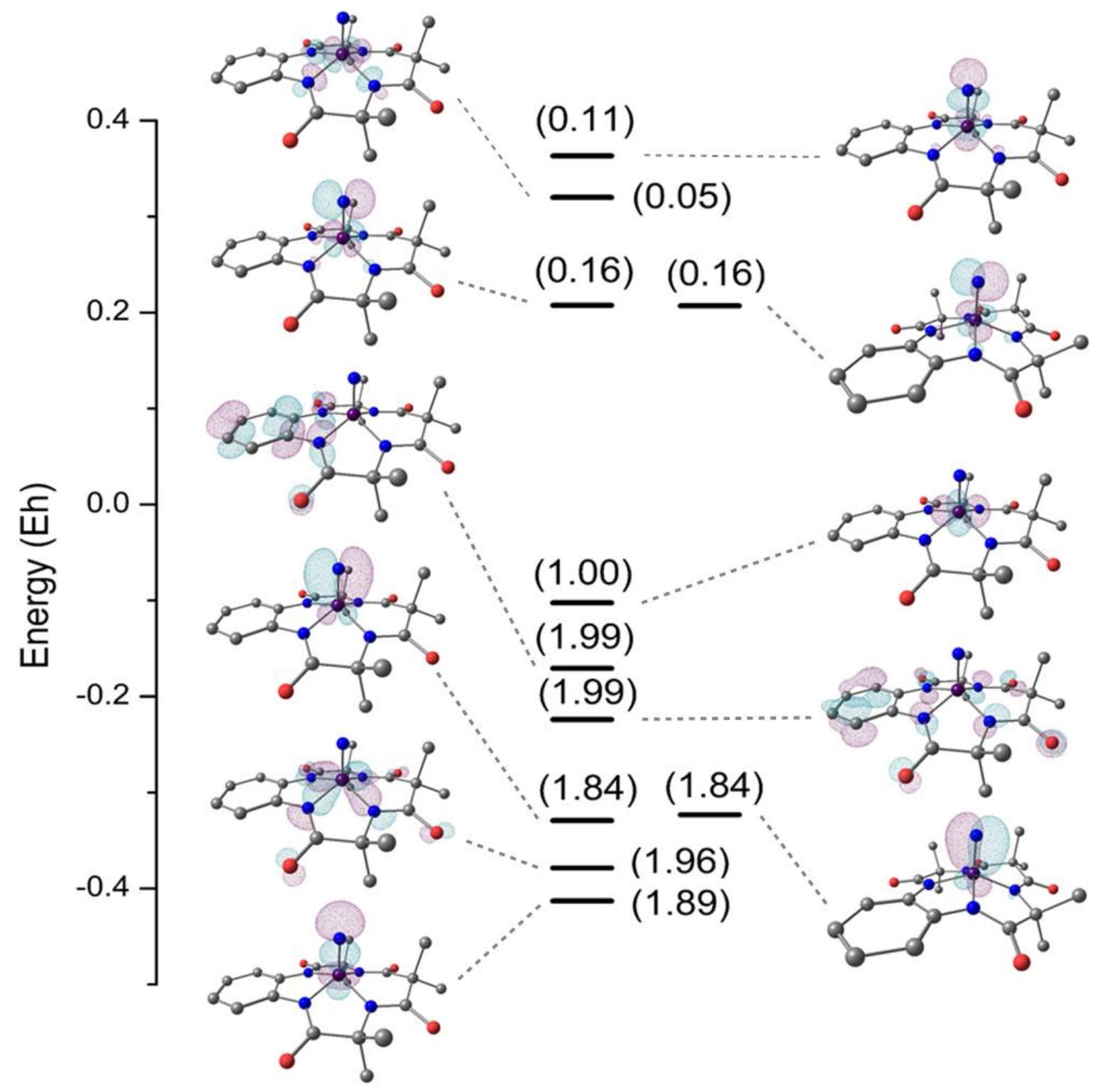

Figure S8. Molecular orbitals in the active space from $\operatorname{CASSCF}(13,11)$ calculations on the equilibrium structure of 2 . 


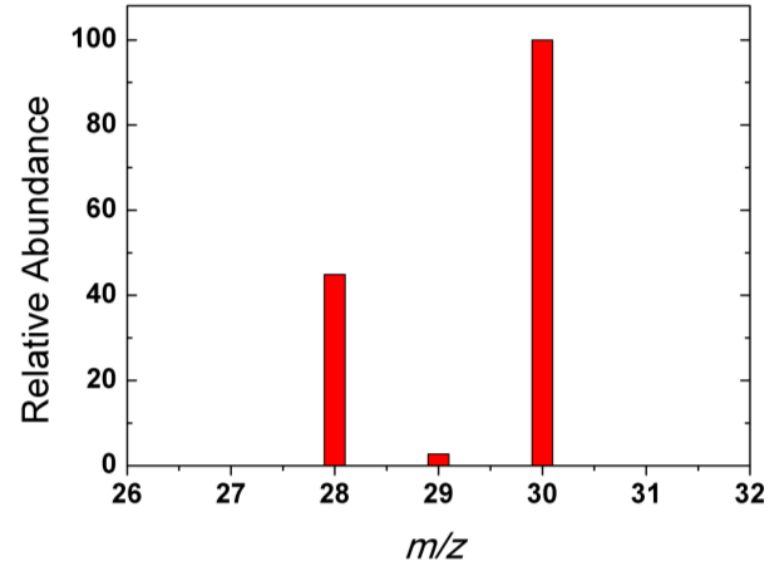

Figure S9. Relative abundance of $\mathrm{N}_{2}$ evolved from $\mathrm{N} \cdots \mathrm{N}$ coupling reaction of $\mathbf{2 - 1 5}^{15} \mathbf{N}$.

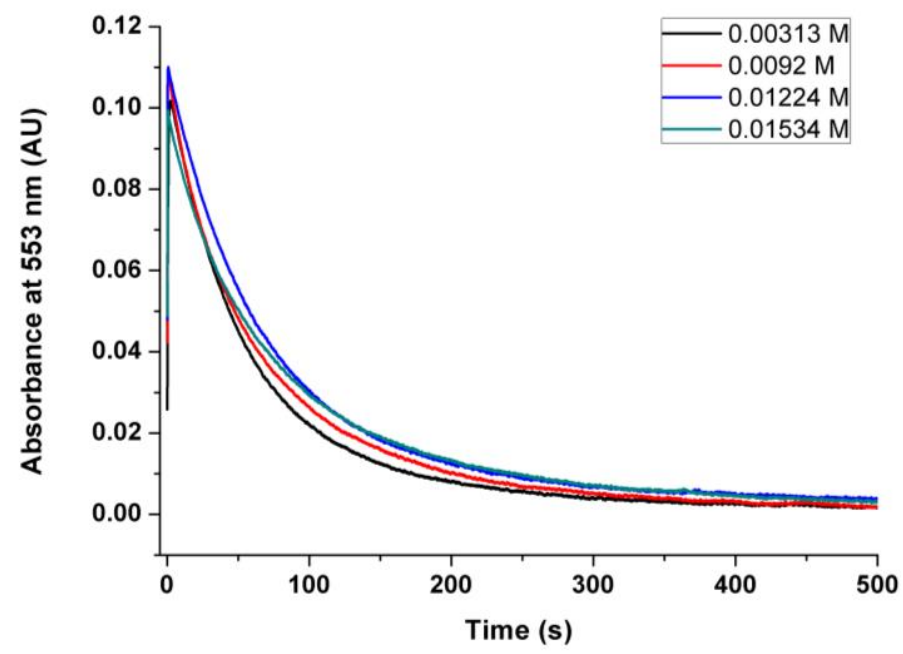

Figure S10. Time trace for the $2^{\text {nd }}$ phase of the reaction between 2 and various $\left[\mathrm{PPh}_{3}\right](3.13-$ $15.3 \mathrm{mM}$ ) in $\mathrm{CH}_{3} \mathrm{CN}$. 


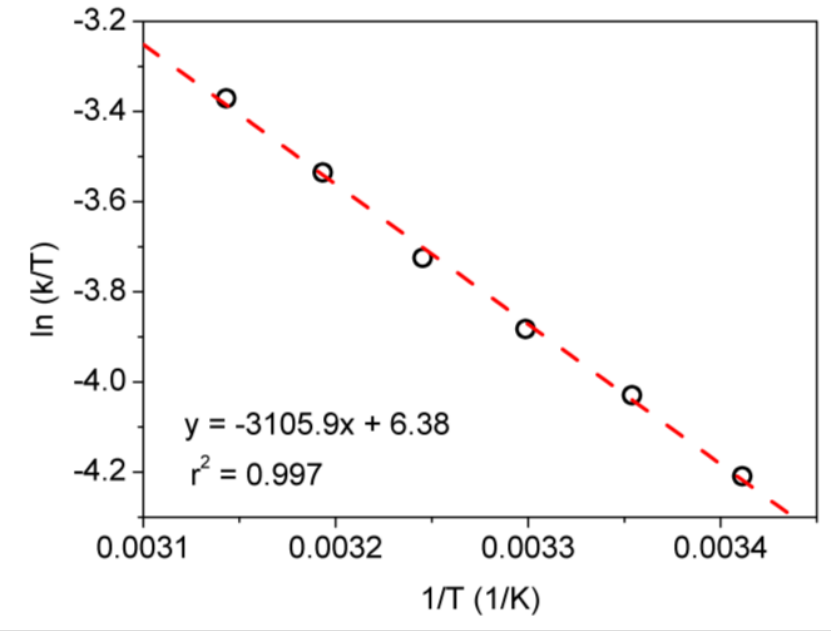

Figure S11. Eyring plot for the $1^{\text {st }}$ phase of the reaction between 2 and $\mathrm{PPh}_{3}$ in $\mathrm{CH}_{3} \mathrm{CN}$.

(a)

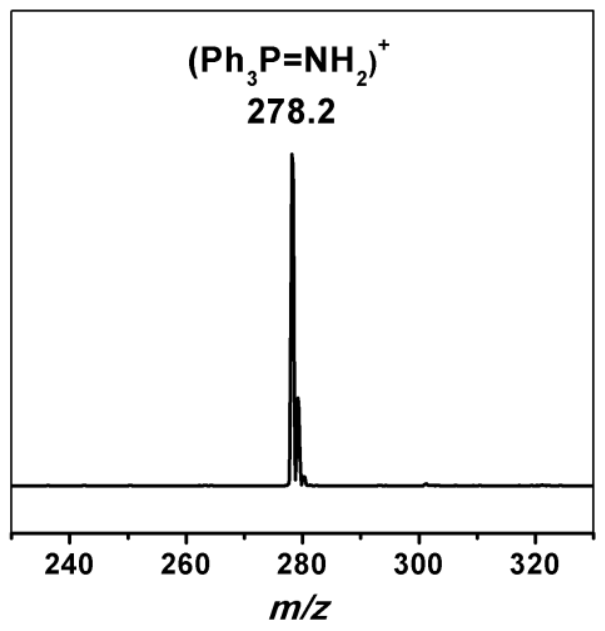

(b)

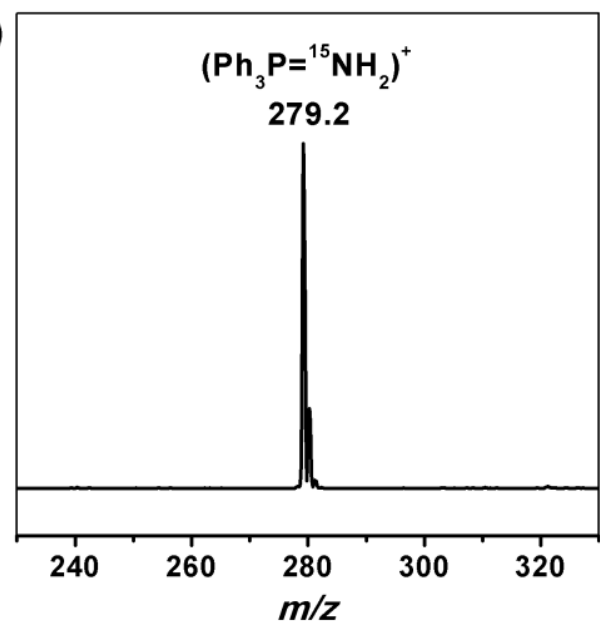

Figure S12. ESI/MS (negative mode) of (a) $\mathrm{Ph}_{3} \mathrm{P}=\mathrm{NH}_{2}{ }^{+}$and (b) $\mathrm{Ph}_{3} \mathrm{P}={ }^{15} \mathrm{NH}_{2}{ }^{+}$. 
(a)

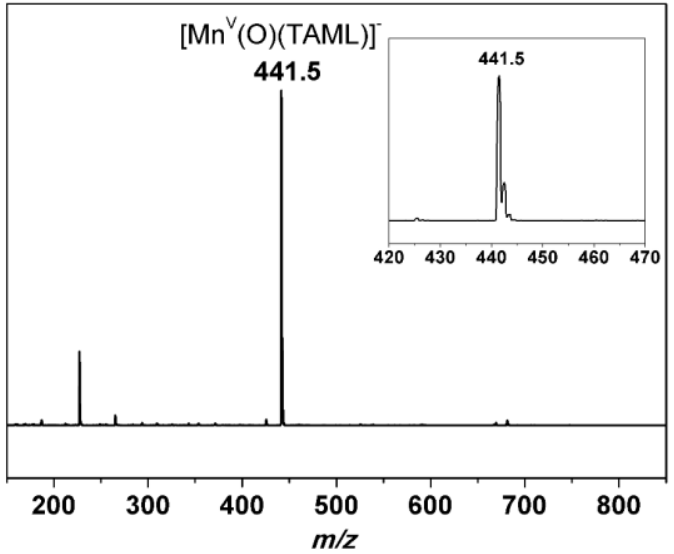

(b)

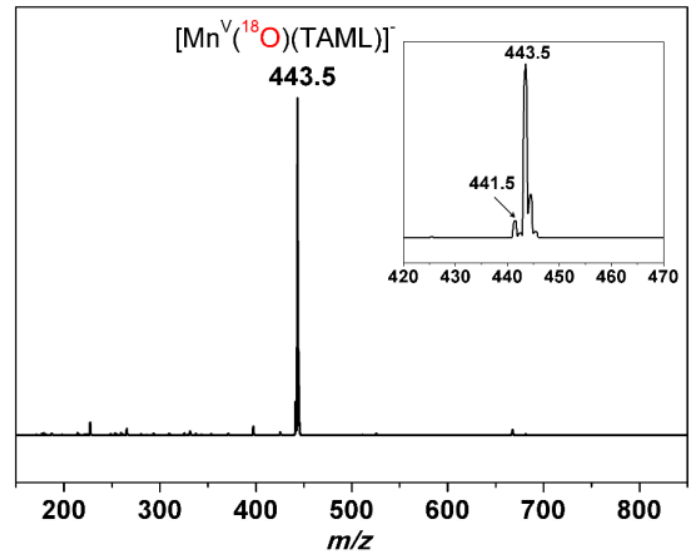

Figure S13. ESI/MS (negative mode) for the reaction of 1 with styrene under various conditions. (a) in air; (b) under ${ }^{18} \mathrm{O}_{2}$.

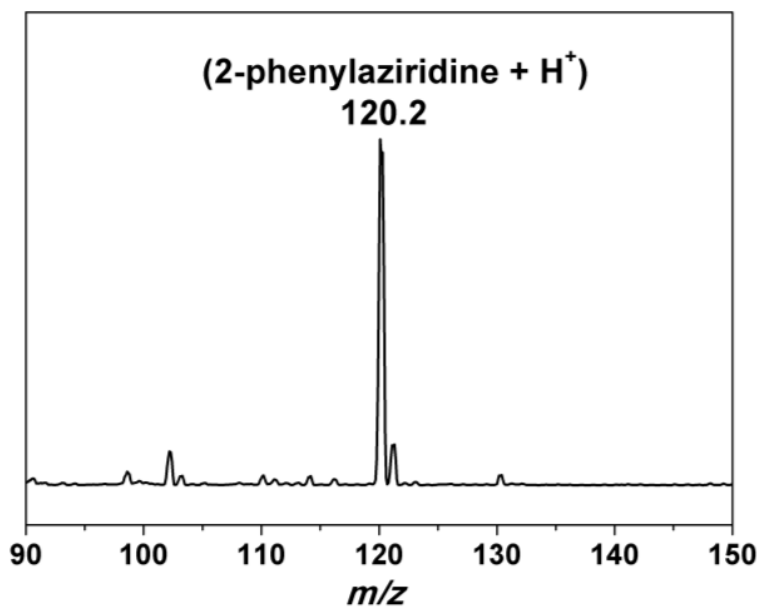

Figure S14. ESI/MS (negative mode) for the reaction mixture of 2 and styrene in $\mathrm{CH}_{3} \mathrm{CN}$. 


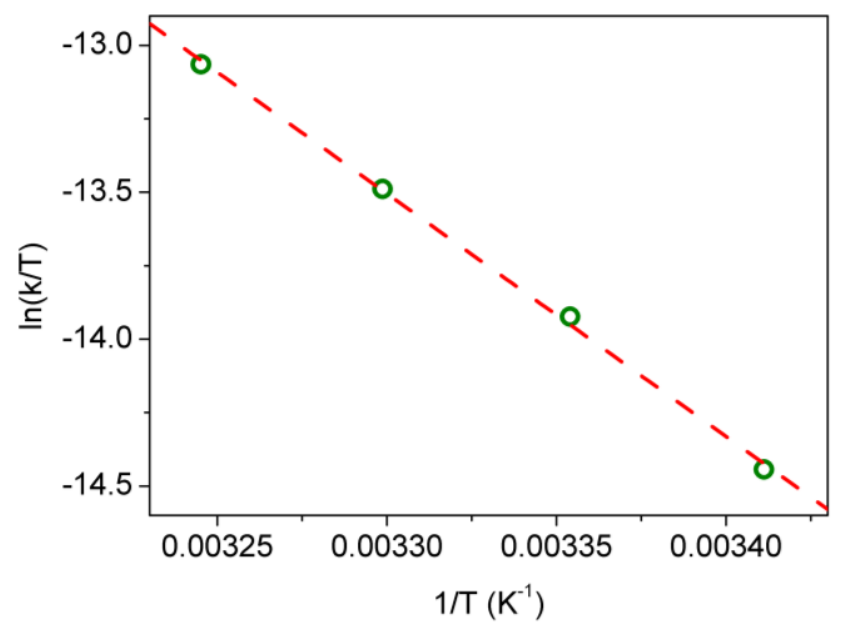

Figure S15. Eyring plot for the reaction between 2 and styrene in $\mathrm{CH}_{2} \mathrm{Cl}_{2}$. Slope $=-(8263 \pm$ $211)$, intercept $=13.76 \pm 0.7$, and $\Delta H^{\star}=16.4 \pm 0.4 \mathrm{kcal} \mathrm{mol}^{-1}$ and $\Delta S^{\dagger}=-19.9 \pm 1.4 \mathrm{cal} \mathrm{K}^{-1}$ $\mathrm{mol}^{-1}$.

(a)

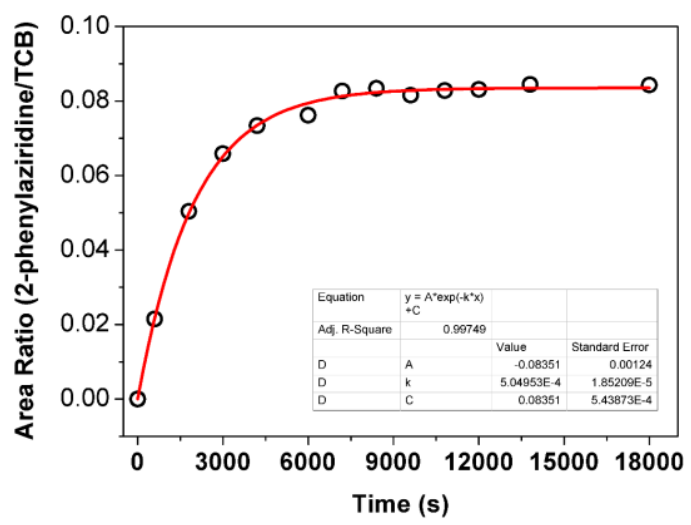

(b)

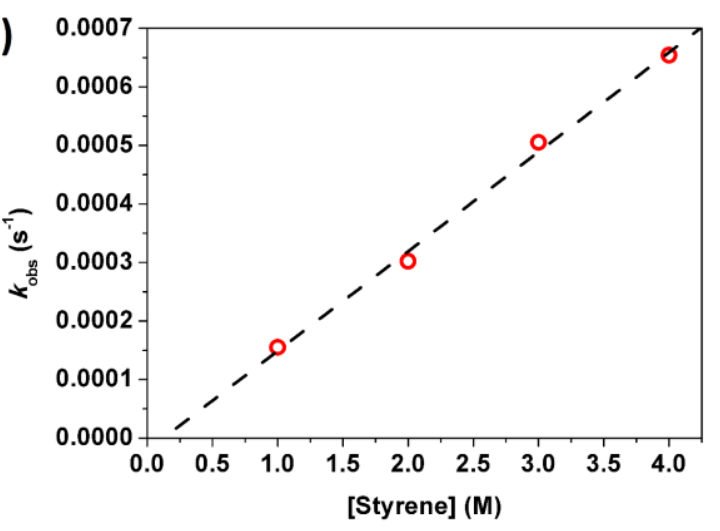

Figure S16. (a) First-order fitting of GC peak area ratio (2-phenylazidine/1,2,4trichlorobenzene(TCB, internal standard)) of reaction between 2 and styrene (3 M) vs time in $\mathrm{CH}_{2} \mathrm{Cl}_{2}, k_{\text {obs }}=5.05 \times 10^{-4} \mathrm{~s}^{-1}$; (b) Linear plot of $k_{\text {obs }}$ of reaction of 2 with various [Styrene] in $\mathrm{CH}_{2} \mathrm{Cl}_{2}, k_{2}=(1.7 \pm 0.1) \times 10^{-4}$, intercept $=(2.1 \pm 2.1) \times 10^{-5}$. 

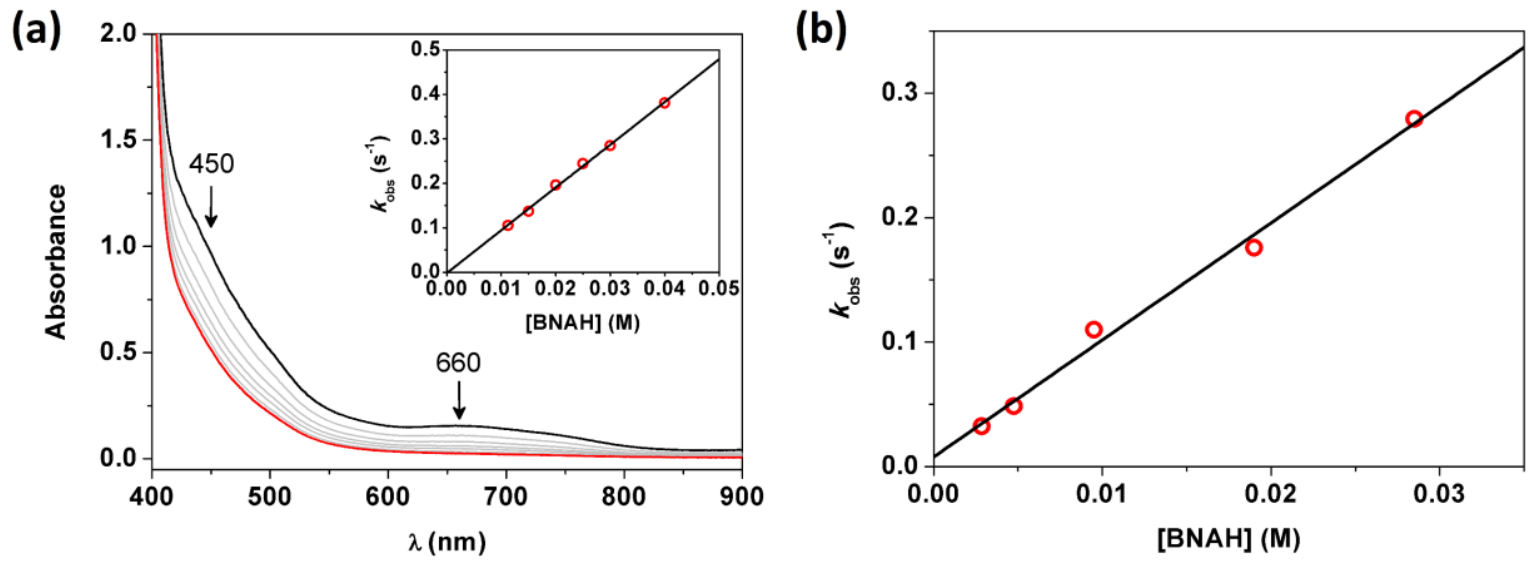

Figure S17. (a) UV-vis spectral changes for the reaction of $2(0.3 \mathrm{mM})$ and BNAH $(0.01 \mathrm{M})$ in $\mathrm{CH}_{3} \mathrm{CN}$ in air at $298 \mathrm{~K}$. Inset shows the second-order plot [slope $=9.61 \pm 0.22$; y-intercept $\left.=(-1.62 \pm 5.54) \times 10^{-3} ; r^{2}=0.997\right]$. (b) The second-order plot done under argon [slope $=9.40$ $\pm 0.48 ;$ y-intercept $\left.=0.01 \pm 0.01 ; r^{2}=0.993\right]$.

(a)

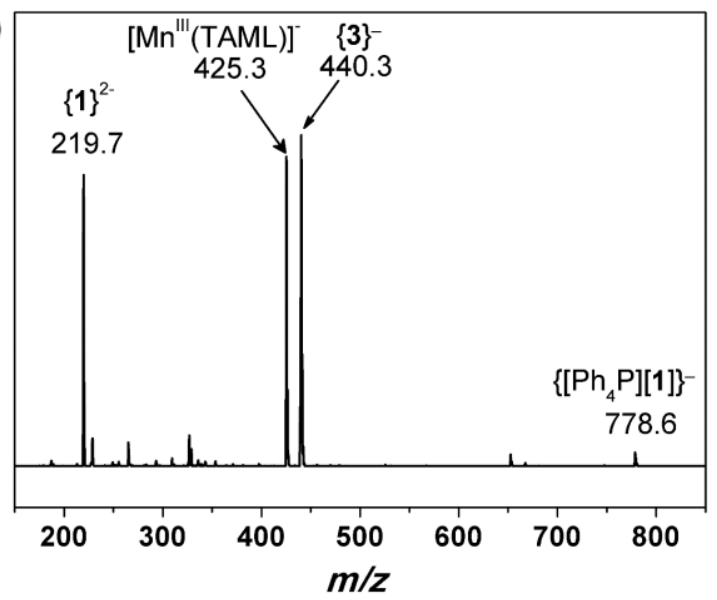

(b)

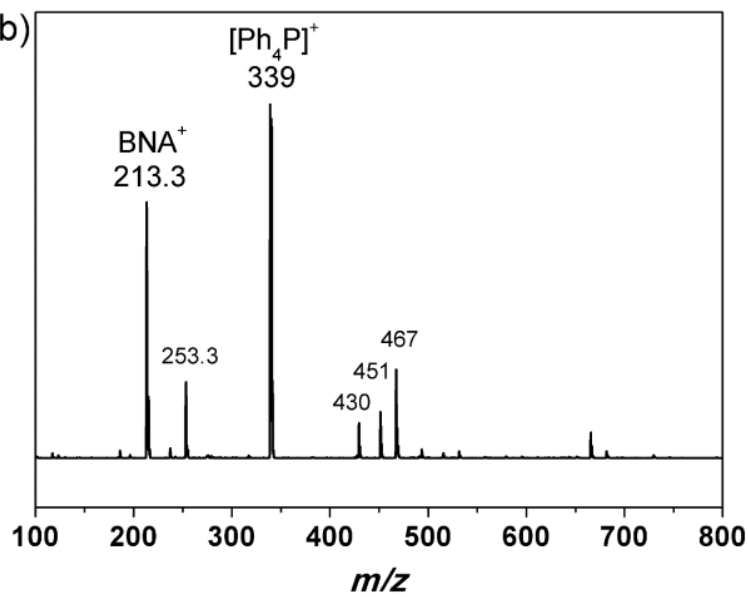

Figure S18. ESI mass spectra for the product solution of 2 and BNAH. (a) negative mode showing the formation of $\left[\mathrm{Mn}^{\mathrm{V}}(\mathrm{N})(\mathrm{TAML})\right]^{2-}$ and $\{[\mathrm{Mn}(\mathrm{N})(\mathrm{TAML})]+\mathrm{H}\}^{-}$at $m / z 219.7$ and 440.3 , respectively, and (b) positive mode showing the formation of $\mathrm{BNA}^{+}$at $m / z, 213.3$. 


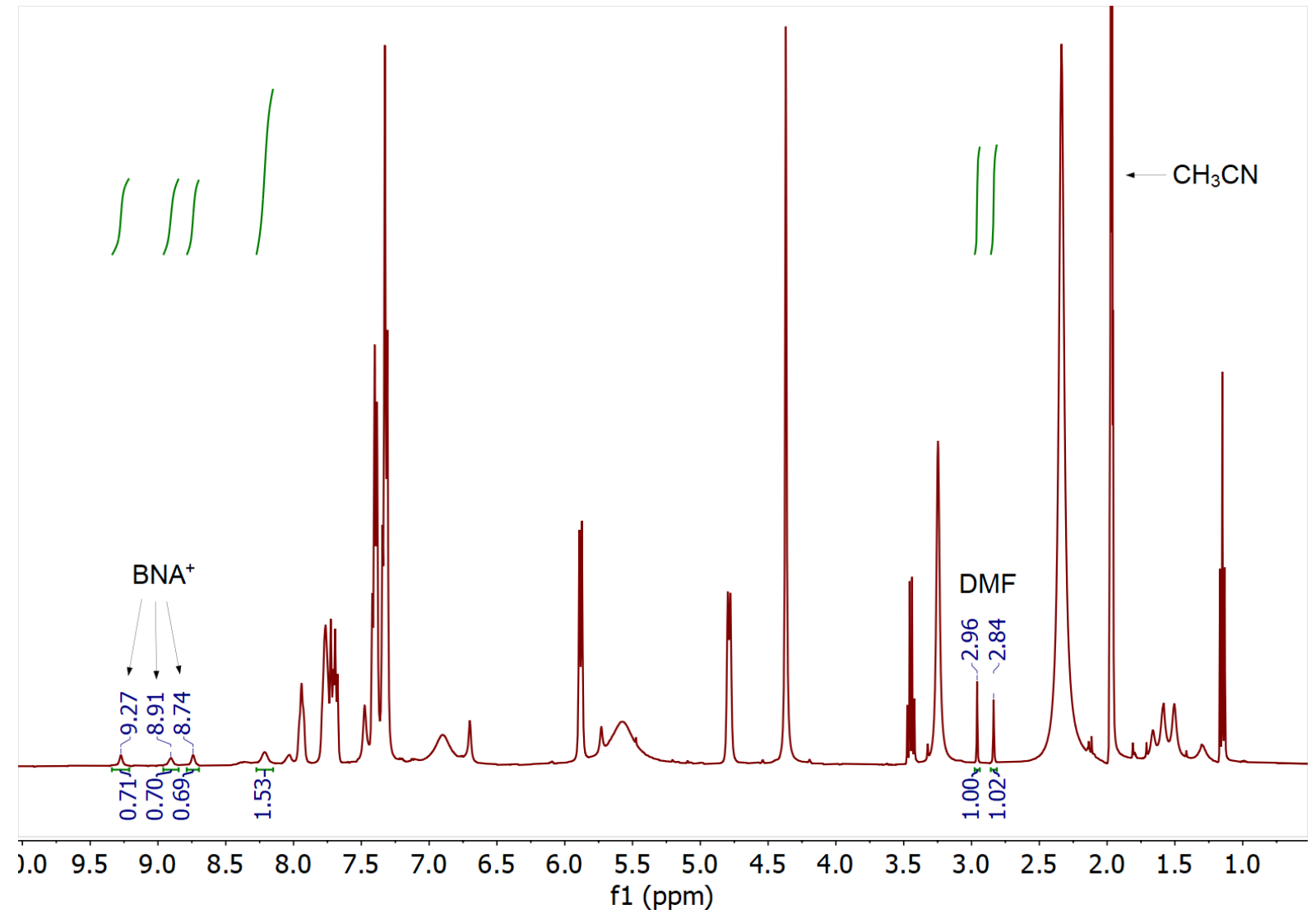

Figure S19. NMR spectrum for the product solution of 2 and $\mathrm{BNAH}$ in $\mathrm{CD}_{3} \mathrm{CN}$ with DMF added as internal standard. 


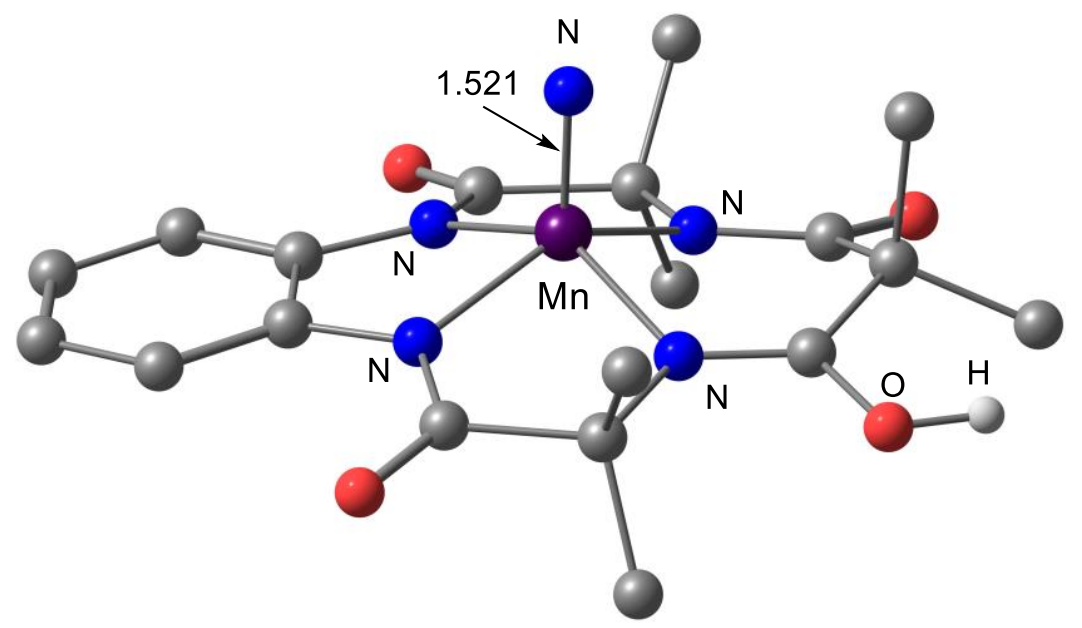

Figure S20. Equilibrium structure of 3 .

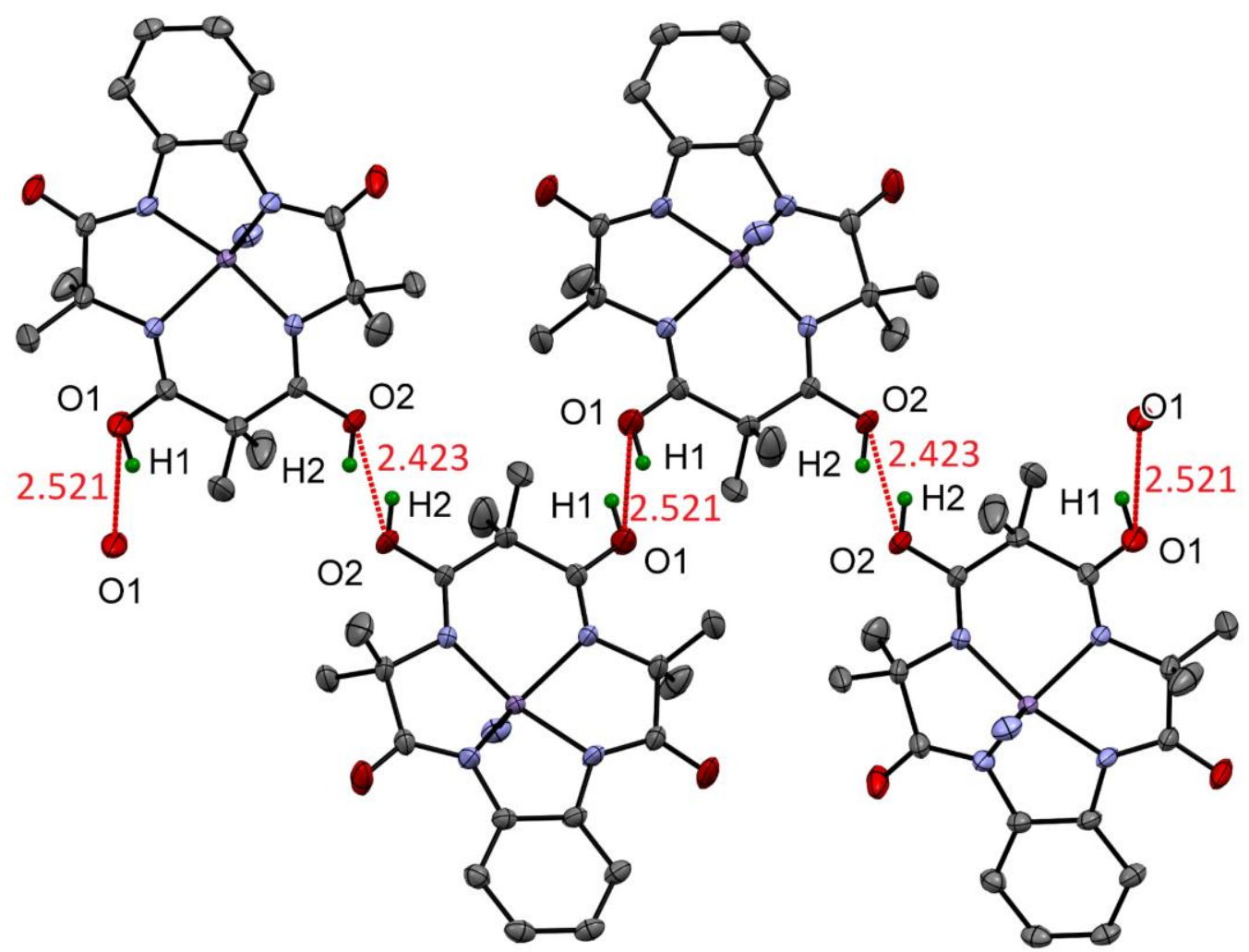

Figure S21. Hydrogen bonding between $\mathrm{O} 1-\mathrm{O} 1$ and $\mathrm{O} 2-\mathrm{O} 2$ in $\mathbf{3}$. 

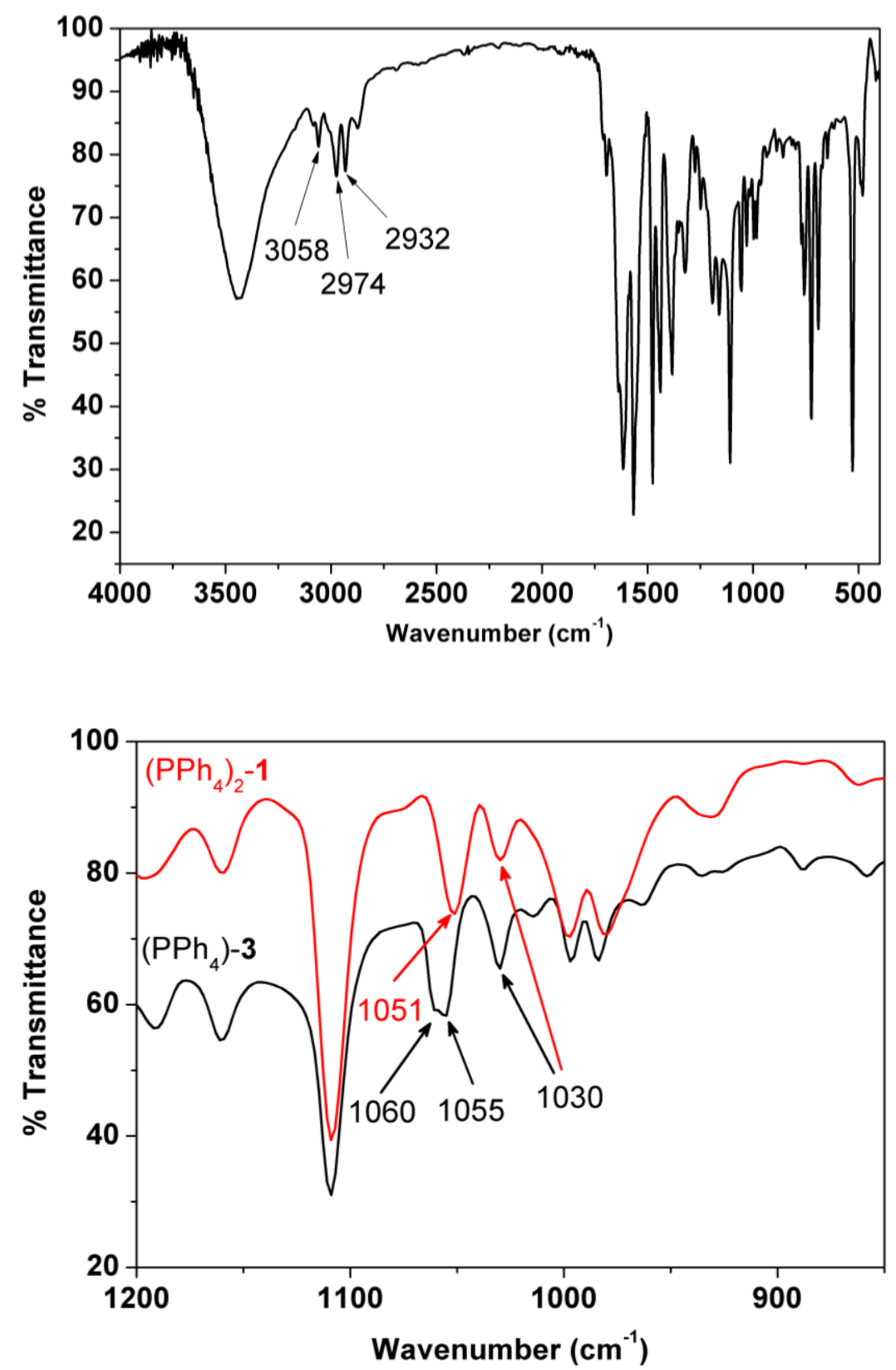

Figure S22. IR spectra of 3 (top). A comparison of 3 (black) and 1 (red) in $850-1200 \mathrm{~cm}^{-1}$ (bottom). 


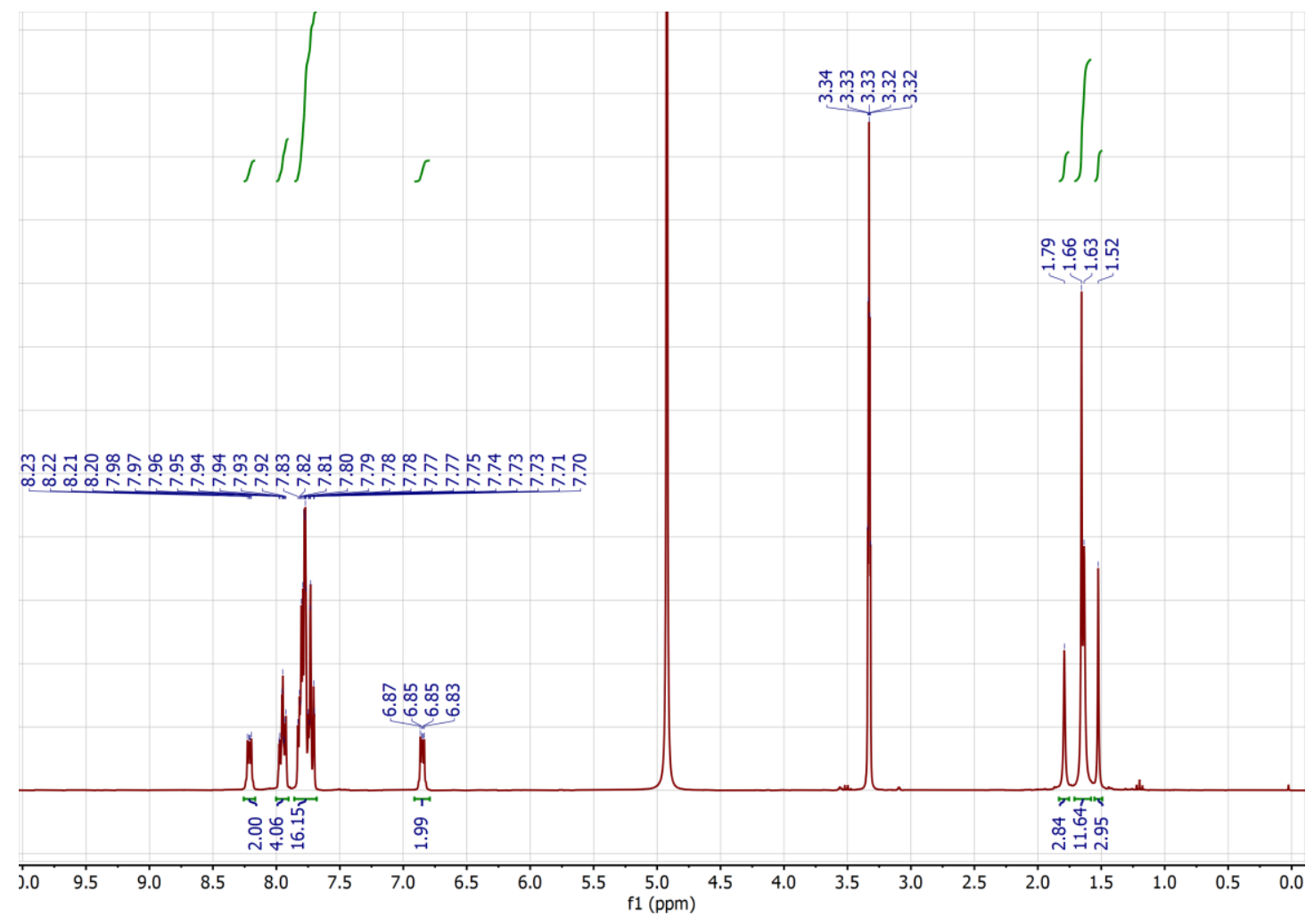

Figure S23. ${ }^{1} \mathrm{H}$ NMR of (PPh4)-3 in $\mathrm{CD}_{3} \mathrm{OD}$. 


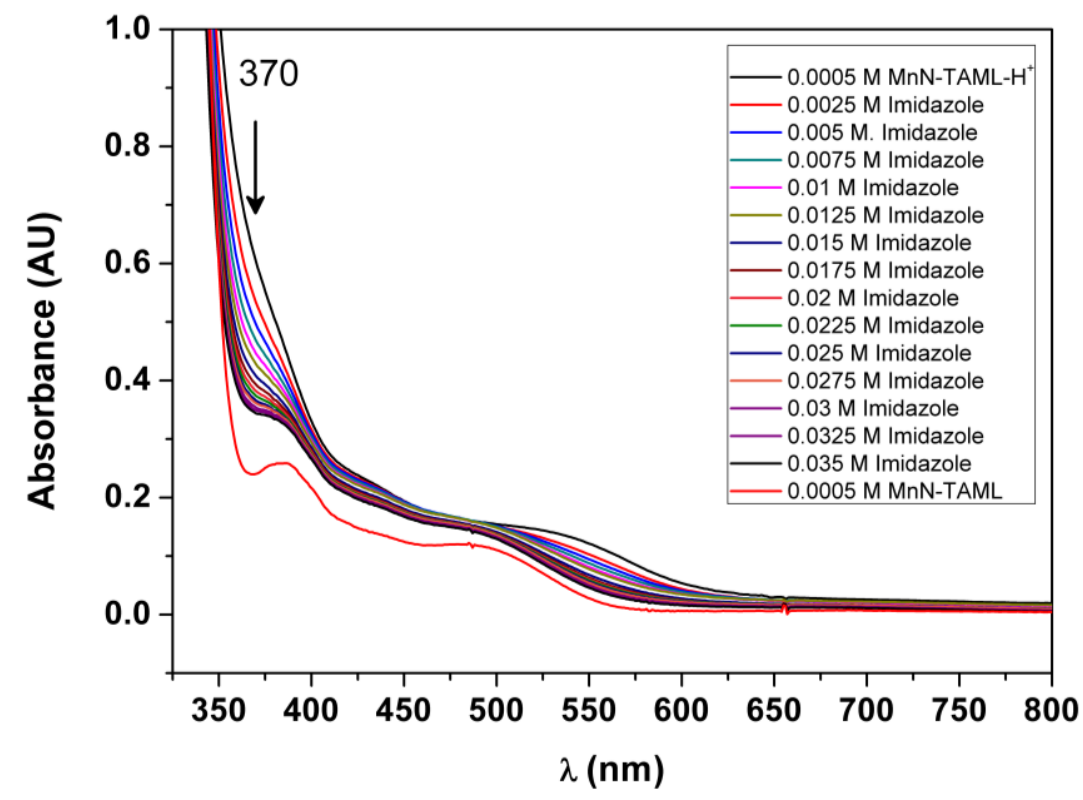

Figure S24. Spectrophotometric titration of $3(0.5 \mathrm{mM})$ with imidazole in $\mathrm{CH}_{3} \mathrm{CN}$ using a 5 cm cuvette.

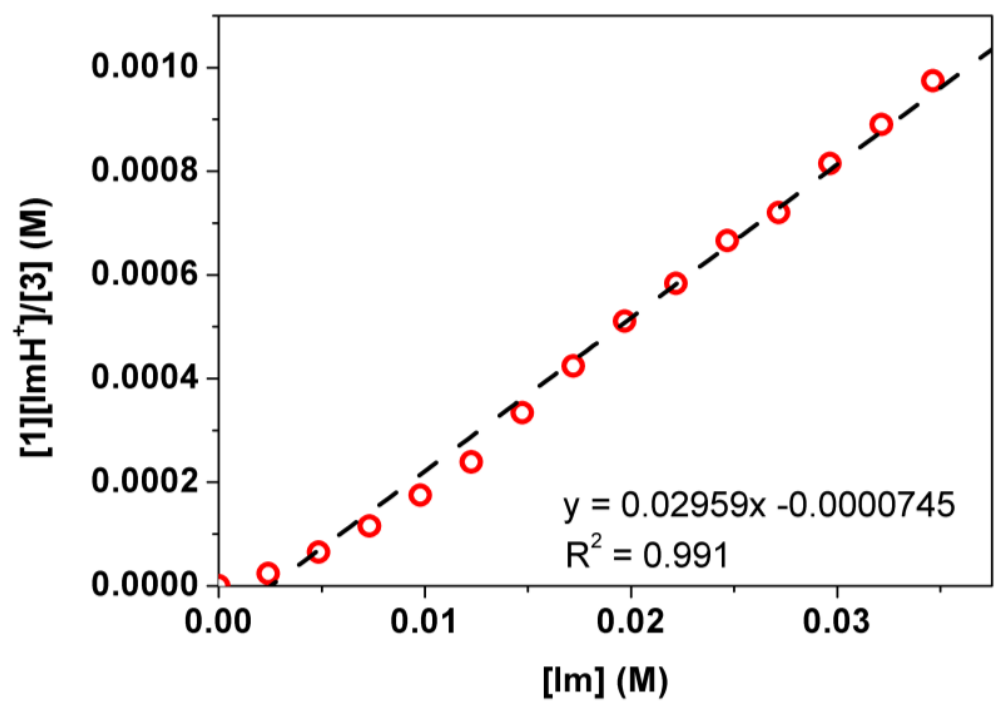

Figure S25. Plot of $[\mathbf{1}]\left[\operatorname{ImH}^{+}\right] /[3]$ vs $[\operatorname{Im}]$. 
Table S1. Crystallographic data of (PPh 4$)_{2}-1,\left(\mathbf{P P h}_{4}\right)-2$ and (PPh4)-3.

\begin{tabular}{|c|c|c|c|}
\hline & $\left(\mathrm{PPh}_{4}\right)_{2}-1 \cdot \mathrm{CH}_{3} \mathrm{CN}$ & $\left(\mathrm{PPh}_{4}\right)-2 \cdot \mathrm{Et}_{2} \mathrm{O}$ & $\left(\mathrm{PPh}_{4}\right)-3$ \\
\hline Formula & $\mathrm{C}_{69} \mathrm{H}_{65} \mathrm{MnN}_{6} \mathrm{O}_{4} \mathrm{P}_{2}$ & $\mathrm{C}_{47} \mathrm{H}_{52} \mathrm{MnN}_{5} \mathrm{O}_{5} \mathrm{P}$ & $\mathrm{C}_{43} \mathrm{H}_{43} \mathrm{MnN}_{5} \mathrm{O}_{4} \mathrm{P}$ \\
\hline$M \mathrm{r}$ & 1159.15 & 852.84 & 779.73 \\
\hline Crystal system & Monoclinic & Triclinic & Monoclinic \\
\hline Space group & $P 21 / \mathrm{c}$ & $P-1$ & $C 2 / c$ \\
\hline$a / \AA$ & $19.8608(8)$ & $12.7449(5)$ & 38.3457 (9) \\
\hline$b / \AA$ & $14.6607(6)$ & $13.1137(6)$ & $12.9098(4)$ \\
\hline$c / \AA$ & $21.4532(9)$ & $13.2167(6)$ & $19.7695(5)$ \\
\hline$\alpha\left(^{\circ}\right)$ & 90.000 & $93.690(3)$ & 90.000 \\
\hline$\beta\left(^{\circ}\right)$ & $114.400(1)$ & $90.151(3)$ & $95.013(1)$ \\
\hline$\left.x^{\circ}\right)$ & 90.000 & $92.096(3)$ & 90.000 \\
\hline$V / \AA^{3}$ & $5688.7(4)$ & $2202.86(17)$ & $9749.2(5)$ \\
\hline$Z$ & 4 & 2 & 8 \\
\hline$\rho_{\mathrm{c}} / \mathrm{Mg} \mathrm{m}^{-3}$ & 1.353 & 1.286 & 1.062 \\
\hline$F(000)$ & 2432 & 898 & 3264 \\
\hline Collected refl. & 11620 & 8034 & 9986 \\
\hline$R$ (int) & 0.1144 & 0.1317 & 0.0618 \\
\hline Final $R$ indices, & $R_{1}(\mathrm{obs})=0.0874$ & $R_{1}(\mathrm{obs})=0.1254$ & $R_{1}(\mathrm{obs})=0.0695$ \\
\hline$I>2 \sigma(I) R$ & $w R($ all $)=0.2371$ & $w R($ all $)=0.3598$ & $w R($ all $)=0.1905$ \\
\hline GOF & 1.032 & 1.293 & 1.111 \\
\hline No. of parameters & 746 & 587 & 511 \\
\hline
\end{tabular}


Table S2. Selected bond lengths ( $\AA$ ) of $\mathbf{1}$.

\begin{tabular}{|c|c|c|c|}
\hline Mn1-N1 & $1.522(4)$ & N2-C19 & $1.344(6)$ \\
\hline Mn1-N2 & $1.915(4)$ & N2-C1 & $1.415(6)$ \\
\hline Mn1-N3 & $1.915(4)$ & N3-C6 & $1.408(6)$ \\
\hline Mn1-N4 & $1.922(4)$ & N3-C7 & $1.345(6)$ \\
\hline Mn1-N5 & $1.938(4)$ & N4-C11 & $1.336(7)$ \\
\hline O1-C19 & $1.224(6)$ & N4-C8 & $1.480(6)$ \\
\hline O2-C7 & $1.241(4)$ & N5-C15 & $1.330(7)$ \\
\hline O3-C11 & $1.247(6)$ & N5-C16 & $1.491(6)$ \\
\hline O4-C15 & $1.252(5)$ & C1-C6 & $1.491(6)$ \\
\hline
\end{tabular}

Table S3. Selected bond angles $\left(^{\circ}\right)$ of $\mathbf{1}$.

\begin{tabular}{|l|l|l|l|l|l|}
\hline$\angle \mathrm{N} 1-\mathrm{Mn} 1-\mathrm{N} 3$ & $106.4(2)$ & $\angle \mathrm{N} 3-\mathrm{Mn} 1-\mathrm{N} 5$ & $145.33(18)$ & $\angle \mathrm{C} 6-\mathrm{N} 3-\mathrm{Mn} 1$ & $115.5(3)$ \\
\hline$\angle \mathrm{N} 1-\mathrm{Mn} 1-\mathrm{N} 2$ & $107.9(2)$ & $\angle \mathrm{N} 2-\mathrm{Mn} 1-\mathrm{N} 5$ & $82.51(18)$ & $\angle \mathrm{C} 11-\mathrm{N} 4-\mathrm{C} 8$ & $118.5(4)$ \\
\hline$\angle \mathrm{N} 3-\mathrm{Mn} 1-\mathrm{N} 2$ & $80.60(18)$ & $\angle \mathrm{N} 4-\mathrm{Mn} 1-\mathrm{N} 5$ & $93.48(18)$ & $\angle \mathrm{C} 11-\mathrm{N} 4-\mathrm{Mn} 1$ & $125.3(3)$ \\
\hline$\angle \mathrm{N} 1-\mathrm{Mn} 1-\mathrm{N} 4$ & $108.4(2)$ & $\angle \mathrm{C} 19-\mathrm{N} 2-\mathrm{C} 1$ & $125.2(4)$ & $\angle \mathrm{C} 8-\mathrm{N} 4-\mathrm{Mn} 1$ & $115.3(3)$ \\
\hline$\angle \mathrm{N} 3-\mathrm{Mn} 1-\mathrm{N} 4$ & $82.41(18)$ & $\angle \mathrm{C} 19-\mathrm{N} 2-\mathrm{Mn} 1$ & $118.9(3)$ & $\angle \mathrm{C} 15-\mathrm{N} 5-\mathrm{C} 16$ & $119.2(4)$ \\
\hline$\angle \mathrm{N} 2-\mathrm{Mn} 1-\mathrm{N} 4$ & $142.98(19)$ & $\angle \mathrm{C} 1-\mathrm{N} 2-\mathrm{Mn} 1$ & $115.8(3)$ & $\angle \mathrm{C} 15-\mathrm{N} 5-\mathrm{Mn} 1$ & $125.4(4)$ \\
\hline$\angle \mathrm{N} 1-\mathrm{Mn} 1-\mathrm{N} 5$ & $107.6(2)$ & $\angle \mathrm{C} 7-\mathrm{N} 3-\mathrm{C} 6$ & $125.7(4)$ & $\angle \mathrm{C} 16-\mathrm{N} 5-\mathrm{Mn} 1$ & $113.8(3)$ \\
\hline$\angle \mathrm{C} 7-\mathrm{N} 3-\mathrm{Mn} 1$ & $118.8(4)$ & & & & \\
\hline
\end{tabular}


Table S4. Selected bond lengths ( $\AA$ ) of 2.

\begin{tabular}{|c|c|c|c|c|c|}
\hline Mn1-N1 & $1.567(8)$ & N3-C6 & $1.423(8)$ & C5-C6 & $1.400(9)$ \\
\hline Mn1-N2 & $1.912(5)$ & N3-C7 & $1.350(8)$ & C7-C8 & $1.527(10)$ \\
\hline Mn1-N3 & $1.903(6)$ & N4-C8 & $1.486(9)$ & C8-C9 & $1.540(10)$ \\
\hline Mn1-N4 & $1.904(5)$ & N4-C11 & $1.355(9)$ & C8-C10 & $1.525(11)$ \\
\hline Mn1-N5 & $1.900(6)$ & N5-C15 & $1.352(9)$ & C11-C12 & $1.546(11)$ \\
\hline O1-C19 & $1.213(7)$ & N6-C16 & $1.482(8)$ & C12-C13 & $1.501(15)$ \\
\hline O2-C7 & $1.228(9)$ & C1-C2 & $1.391(8)$ & C12-C14 & $1.565(9)$ \\
\hline O3-C11 & $1.225(8)$ & C1-C6 & $1.407(8)$ & C12-C15 & $1.565(9)$ \\
\hline O4-C15 & $1.227(9)$ & C2-C3 & $1.382(10)$ & C16-C18 & $1.522(11)$ \\
\hline N2-C1 & $1.411(8)$ & C3-C4 & $1.378(10)$ & C16-C17 & $1.526(10)$ \\
\hline N2-C19 & $1.363(8)$ & C4-C5 & $1.373(10)$ & C16-C19 & $1.544(9)$ \\
\hline
\end{tabular}

Table 5. Selected bond angles $\left(^{\circ}\right)$ for 2.

\begin{tabular}{|c|c|c|c|}
\hline$\angle \mathrm{N} 1-\mathrm{Mn} 1-\mathrm{N} 2$ & $105.4(3)$ & $\angle \mathrm{N} 2-\mathrm{Mn} 1-\mathrm{N} 4$ & $146.3(2)$ \\
\hline$\angle \mathrm{N} 1-\mathrm{Mn} 1-\mathrm{N} 3$ & $104.9(4)$ & $\angle \mathrm{N} 2-\mathrm{Mn} 1-\mathrm{N} 5$ & $82.3(2)$ \\
\hline$\angle \mathrm{N} 1-\mathrm{Mn} 1-\mathrm{N} 4$ & $107.0(3)$ & $\angle \mathrm{N} 3-\mathrm{Mn} 1-\mathrm{N} 4$ & $82.3(2)$ \\
\hline$\angle \mathrm{N} 1-\mathrm{Mn} 1-\mathrm{N} 5$ & $108.0(3)$ & $\angle \mathrm{N} 3-\mathrm{Mn} 1-\mathrm{N} 5$ & $145.9(3)$ \\
\hline$\angle \mathrm{N} 2-\mathrm{Mn} 1-\mathrm{N} 3$ & $80.7(2)$ & $\angle \mathrm{N} 4-\mathrm{Mn} 1-\mathrm{N} 5$ & $96.3(2)$ \\
\hline
\end{tabular}


Table S6. Occupation and energy (Eh) of orbitals in the active space from $\operatorname{CASSCF}(13,11)$ calculation of $\mathbf{2}$.

\begin{tabular}{|l|c|c|}
\hline \multicolumn{1}{|c|}{ Orbital } & Occupation & Energy \\
\hline $109($ TAML $\pi$ orbital $)$ & 1.99994 & -0.22795 \\
\hline $110($ TAML $\pi$ orbital $)$ & 1.99885 & -0.17477 \\
\hline $111(\mathrm{Mn}-4 \mathrm{~N} \sigma)$ & 1.95622 & -0.38265 \\
\hline $112\left(\mathrm{Mn} \equiv \mathrm{N}\left(\mathrm{P}_{\mathrm{z}}\right)\right)$ & 1.89065 & -0.41718 \\
\hline $113\left(\mathrm{Mn} \equiv \mathrm{N}\left(\mathrm{P}_{\mathrm{x}} / \mathrm{P}_{\mathrm{y}}\right)\right)$ & 1.83829 & -0.32725 \\
\hline $114\left(\mathrm{Mn} \equiv \mathrm{N}\left(\mathrm{P}_{\mathrm{x}} / \mathrm{P}_{\mathrm{y}}\right)\right)$ & 1.8377 & -0.3334 \\
\hline $115\left(\mathrm{Mn} \mathrm{d}_{\mathrm{x} y}\right)$ & 1.00032 & -0.10645 \\
\hline $116\left(\mathrm{Mn} \equiv \mathrm{N} \mathrm{d}-\pi^{*}\right)$ & 0.16223 & 0.20296 \\
\hline $117\left(\mathrm{Mn} \equiv \mathrm{N} \mathrm{d}-\pi^{*}\right)$ & 0.16155 & 0.20346 \\
\hline $118\left(\mathrm{Mn} \mathrm{d}_{\mathrm{z}}{ }^{2}\right)$ & 0.10857 & 0.35913 \\
\hline $119\left(\mathrm{Mn} \mathrm{d}_{\mathrm{x}}{ }^{2}-{ }_{\mathrm{y}}{ }^{2}\right)$ & 0.04568 & 0.31588 \\
\hline
\end{tabular}

Table S7. Occupation pattern and configuration interaction (CI) coefficients of state 1 from $\operatorname{CASSCF}(13,11)$ calculation of 2.

\begin{tabular}{|c|c|}
\hline Occupation pattern & $\mathrm{Cl}$ coefficients \\
\hline $222222 \mathrm{a} 0000$ & 0.8788257 \\
\hline $222220 a 2000$ & -0.1663898 \\
\hline $222202 \mathrm{a} 0200$ & -0.1659629 \\
\hline $222022 \mathrm{a} 0020$ & -0.1089734 \\
\hline 2222a2b0a00 & -0.0983612 \\
\hline 22222aba000 & 0.0970779 \\
\hline 2222baaba00 & -0.0916348 \\
\hline 2222abaab00 & -0.0915899 \\
\hline $220222 a 0002$ & -0.090439 \\
\hline 222ba2a0ba0 & -0.0807605 \\
\hline 222b2aab0a0 & 0.0807073 \\
\hline 222a2baa0b0 & 0.0806227 \\
\hline 222ab2a0ab0 & -0.0805561 \\
\hline $222 \mathrm{a} 22 \mathrm{~b} 00 \mathrm{a} 0$ & 0.0641534 \\
\hline 2222b2a0a00 & 0.0616781 \\
\hline 22222baa000 & -0.0609724 \\
\hline $222200 a 2200$ & 0.0556406 \\
\hline 2222baaab00 & 0.0533011 \\
\hline 2222ababa00 & 0.0532782 \\
\hline 222bb2a0aa0 & 0.0514126 \\
\hline $222 \mathrm{~b} 2 \mathrm{baaOa0}$ & -0.051112 \\
\hline
\end{tabular}


Table S8. Reaction rates of 2 and $p$-X-styrene in $\mathrm{CH}_{2} \mathrm{Cl}_{2}$.

\begin{tabular}{cc}
\hline $\mathrm{X}$ & $k_{2}\left(\mathrm{M}^{-1} \mathrm{~s}^{-1}\right)$ \\
\hline $\mathrm{H}$ & $(1.64 \pm 0.10) \times 10^{-4}$ \\
$\mathrm{Me}$ & $(2.10 \pm 0.10) \times 10^{-4}$ \\
$\mathrm{Cl}$ & $(1.60 \pm 0.03) \times 10^{-4}$ \\
$\mathrm{MeO}$ & $(3.10 \pm 0.10) \times 10^{-4}$ \\
$\mathrm{~F}$ & $(1.46 \pm 0.08) \times 10^{-4}$ \\
$\mathrm{CF}_{3}$ & $(2.37 \pm 0.08) \times 10^{-4}$ \\
$\mathrm{CN}^{-4}$ & $(2.73 \pm 0.14) \times 10^{-4}$ \\
\hline
\end{tabular}

Table S9. Selected bond lengths ( $\AA$ ) of $\mathbf{3}$.

\begin{tabular}{|c|c|c|c|}
\hline Mn1-N1 & $1.524(4)$ & Mn1A-N1A & $1.565(9)$ \\
\hline Mn1-N2 & $1.955(2)$ & Mn1A-N2 & $2.007(3)$ \\
\hline Mn1-N3 & $1.943(2)$ & Mn1A-N3 & $2.014(3)$ \\
\hline Mn1-N4 & $1.954(3)$ & Mn1A-N4 & $2.006(3)$ \\
\hline Mn1-N5 & $1.973(3)$ & Mn1A-N5 & $1.969(3)$ \\
\hline O1-C1 & $1.282(4)$ & O3-C5 & $1.228(4)$ \\
\hline O2-C3 & $1.288(3)$ & O4-C12 & $1.221(4)$ \\
\hline
\end{tabular}


Table S10 Cartesian coordinates of the optimized geometries.

$$
[\mathrm{Mn}(\mathrm{V})(\mathrm{N})(\mathrm{TAML})]^{2-}(\mathrm{S}=0)
$$

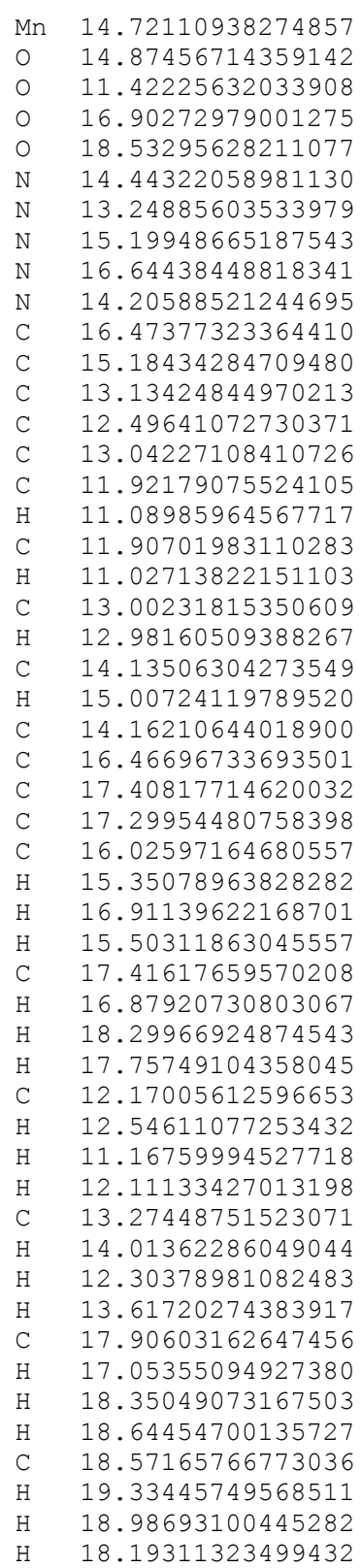

3.78919020603296 4.43886044337672 1. 79554203944718 2.30761181280903 4.77887905309427 3.70276486617157 2.53737720740120 2. 72178016800363 3.90769952606988 5.13785157432593 5.07858642070496 4.33451441623117 3. 14324927433219 2. 41810872747821 1.86061576078888 1.10810201771666 1.03146897693396 0.47383268889018 $-0.10422043002266$ 0.57698070055383 0.08008106833433 1. 31687613531731 1.40088130907947 1. 96631086520886 2.78980487009230 3.54249670474153 4. 53100383917686 6.50758527983587 6.47167117202438 7.11059220661952 6.97959561689228 5.18706478158836 5.64563284716100 5.77477782845110 4.19096634911403 4.26860964468440 4.75210906953671 3. 84884183986064 5. 01381453822347 2.08459846671246 1.32876551995633 1.58769120419293 2.55960331576818 4.80506654484335 5.47620335846036 4. 52132133917525 5. 32197754521776 2. 57939319702671 3.09364154135829 2. 21135504380394 1. 71955350720214
8.41053642518407 12.46701824634735 9.64891035013533 5.33779537029864 9.58975048384643 10.32416092951964 8.40824259686901 6.87189787788716 8.59263215650239 7. 91792577391859 10.79147715495378 11.25209508752416 10.73770143669753 9.52678038651772 7.20540418768780 6.82320034089655 7.52002229865771 5.57200473450068 5.27413840163769 4.70962732602371

3.73510330267369 5.08039231049203 4.43556345406641 6.32347769312508 6.40263286199496 7.37555585115997 9.58857121388563 10.39006869089956 9. 52396800494192 10.13358495084575 11.23689984417086 12.00301383021762 12.84219234452598 11.72592428854744 12.32263718978993 11.15795907091802 12.06857109915575 11.33019674821406 10.35067447279131 11.84876115137621 11.54185323933629 11.99108700116425 12.77445023538523 6.64689382139016 6.46435873061927 5.68106923455454 7.27284414186753 7.68105445705524 8.27569460644446 6.73152544257797 8.25479515020657

\section{$[\mathrm{Mn}(\mathrm{VI})(\mathrm{N})(\mathrm{TAML})]^{-}(\mathrm{S}=1 / 2)$}

$\begin{array}{ll}\mathrm{Mn} & 14.73944147778982 \\ \mathrm{O} & 14.90170326217660 \\ \mathrm{O} & 11.52007649085758 \\ \mathrm{O} & 16.90654832048299 \\ \mathrm{O} & 18.49995541084164 \\ \mathrm{~N} & 14.44521845015384 \\ \mathrm{~N} & 13.26771704727002 \\ \mathrm{~N} & 15.20031347462715 \\ \mathrm{~N} & 16.63757762211015 \\ \mathrm{~N} & 14.18583769973678 \\ \mathrm{C} & 16.42714683368808 \\ \mathrm{C} & 15.19325794513935 \\ \mathrm{C} & 13.18837724538288 \\ \mathrm{C} & 12.55409267298332 \\ \mathrm{C} & 13.02011778763908\end{array}$

3. 77066249415673 4.43713770561107 1.68722908035013 2.17800642255424 4.77799397404771 3. 70850805533661 2.54189336560935 2. 71922415141545 3.90941239023367 5.08198164185822 5.18778027437081 4.38754867004668 3.06255586443410 2. 35563077943577 1.92886178551281
8.43106113998570 12.43937368120863 9.66304205019019 5.43238144448706 9.60469719072764 10.31717263378431 8.41403147146354 6.89520249859240 8.59442730844330 7.87812297444431 10.74424525094454 11.23177756965318 10.77153350477131 9.56089542017333

7.18035620790833 


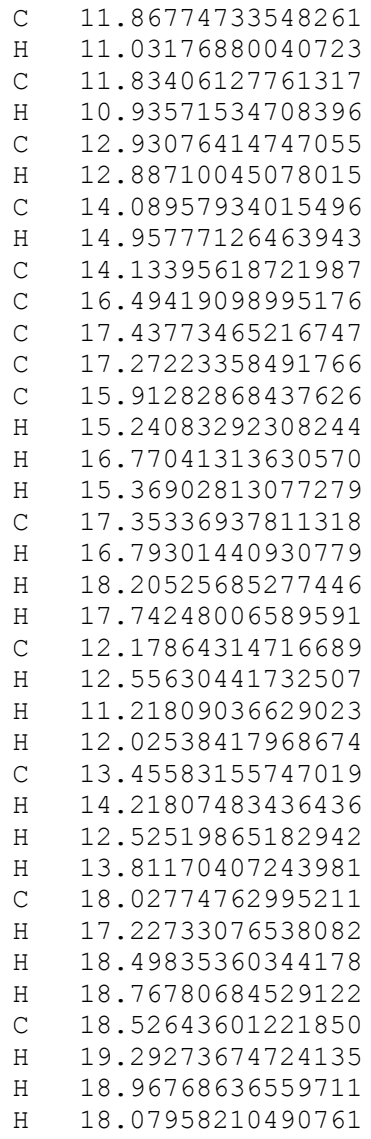

1. 24259114423336 1.16517167127714 0.66562962617335 0.13454246356762 0.76632373990294 0.31378073518264 1. 44638931534537 1.52549133601589 2.03096850521870 2. 71649480369930 3.45733757597600 4. 58216056098131 6.56622867405446 6.47314981095430 7.19113930617709 7.06208232850568 5.41662805529462 5.90444688848222 6.03405379609246 4. 46408151415640 4.10885501561678 4.58069797748625 3. 61446733262132 4. 88053179106361 1. 97281187095298 1.27330369341204 1. 41630906212884 2.42777634026543 4. 65564301575657 5.36179770509855 4. 29518676682080 5.16746168153744 2.45044174628195 2. 95007886362742 2.01990673688199 1. 63830189418382
6.78011346815410 7.47030927835673 5.50595443750873 5.18505559014004 4.64403201380085 3.65138534058300 5.03410631980078 4.38510557253799 6.30511707483963 6.46504665577775 7.42861782209754 9.59536989519557 10.25364736122614 9.39080814057831 9.96508123322782 11.07074220868146 11.94822568595981 12.75351580032522 11.64238063659234 12.33185849186201 11.27535055006330 12.18918111872715 11.47373977747902 10.50701361068698 11.82476699113098 11.45240341695890 11.99887579357153 12.75424482643324 6.66394541023583 6.39945608999073 5.73923611777145 7.28909210387689 7.83939448062791 8.43991536296186 6.93053258706575 8. 43074838839477

\section{$\left[\mathrm{Mn}(\mathrm{V})(\mathrm{N})\left(\mathrm{TAML}^{+} \mathrm{H}^{+}\right)\right]^{-}(\mathrm{S}=0)$}

$\begin{array}{ll}\mathrm{Mn} & 23.27389797711853 \\ \mathrm{~N} & 23.59913435636721 \\ \mathrm{O} & 20.10800513497938 \\ \mathrm{H} & 19.18902342635298 \\ \mathrm{O} & 19.68746304603071 \\ \mathrm{O} & 24.42880329542077 \\ \mathrm{O} & 24.97297508643125 \\ \mathrm{~N} & 22.08983306513132 \\ \mathrm{~N} & 21.86203988048280 \\ \mathrm{~N} & 24.33458020316565 \\ \mathrm{~N} & 24.51822726882794 \\ \mathrm{C} & 20.84628122809529 \\ \mathrm{C} & 20.12139227210773 \\ \mathrm{C} & 20.57450358314396 \\ \mathrm{C} & 22.32597265534711 \\ \mathrm{C} & 23.82587164053835 \\ \mathrm{C} & 25.59384871890452 \\ \mathrm{C} & 26.67331892014388 \\ \mathrm{H} & 26.56499562834788 \\ \mathrm{C} & 27.85301776681878 \\ \mathrm{H} & 28.69771709878186 \\ \mathrm{C} & 27.95865932294192 \\ \mathrm{H} & 28.88528528496372 \\ \mathrm{C} & 26.88421504609824 \\ \mathrm{H} & 26.93978852910984 \\ \mathrm{C} & 25.70185855863362 \\ \mathrm{C} & 24.23362269652726 \\ \mathrm{C} & 22.77677912504378 \\ \mathrm{C} & 20.36306860142530 \\ \mathrm{H} & 19.82101076681587 \\ \mathrm{H} & 19.99028876547602 \\ \mathrm{H} & 21.43423595723262 \\ \mathrm{C} & 18.60556035063524 \\ \mathrm{H} & 18.15460623010574 \\ \mathrm{H} & 18.37681157722706 \\ \mathrm{H} & 18.12800120673530 \\ \mathrm{C} & 22.19783934262643\end{array}$
4. 69123430202685
2.54298319702165 6.11251580394468 5.47553259223829 5.61906983820974 4.11075761493251 2.27585991220085 4. 21542167117094 4.88033936854976 4.02132749208034 3. 47725436749788 4.14557668094473 5.17420200018169 5.32245371281988 4.37591031869205 3. 29683839457421 2. 96395259811376 3.18200568464949 2. 55914187737072 2. 26341519087662 2. 32737792017929 1.84904684366782 2.70228708677081 2. 51806965040559 3. 31692331014832 3. 60453421089733 3. 56178508371284 4. 37448774948742 4.87396583194664 6.77229896483341 6.90696930890122 7. 50644586828366 6.94303417051050 5.11164272502656 5.07112904707614 4. 15846611802423 5.94631953725689 4.18837188842798 2. 97715808602269 0.00765565973874 0.30886280159560 4. 46325125412267 5.55302342248396 $-1.10294586137373$ 0.98355486552775 3. 68307577548807 3.56518544524348 1. 18138577511060 1.11608241910127 2. 44233969751219 3. 62252101046829 4.89591104509964 4.71654336460622 3.02888483361507 3.66911990921816 4.70955813819498 2. 95121886783281 3. 45241119595038 1. 60927021211242 1.06093508136948 0.95373136926834 $-0.09318199465558$ 1.66216560153615 $-0.11877666909257$ $-0.34057951435141$ 2.94174660413915 3. 88777945508651 2. 21033293908720 3. 11116823367672 2. 24882446123213 3. 24654572170617 1. 74901746942457 1. 70201518871470 6.14290068206315 


\begin{abstract}
22.67717898746952
21.14058571071251

22.70823794979567

21.59761914536398

22.10233396882741

21.65148479872988

20.54607500287257

22.86410631272881

23.53378300087942

23.28739017559351

21.87744558457396

22.12648525197896

22.82976905432414

21.17306766548998

21.95754377652241
\end{abstract}
3.68614364628899
6.99447449634801
4.37741630255270
5.14629784519810
1.95511279801747
1.38980395887088
1. 36983249162947
2.12395099257408
6.30510605019131
6.29760415980338
6.97127010269412
6.67960348302567
3. 90250762260592
3. 76132913828891
4.28300334571283
2. 92753332591428 